\title{
Contrasting trends in floods for two sub-arctic catchments in northern Sweden - does glacier presence matter?
}

\author{
H. E. Dahlke ${ }^{1}$, S. W. Lyon ${ }^{1,2}$, J. R. Stedinger ${ }^{3}$, G. Rosqvist ${ }^{1}$, and P. Jansson ${ }^{1}$ \\ ${ }^{1}$ Department of Physical Geography and Quaternary Geology, Stockholm University, 10691 Stockholm, Sweden \\ ${ }^{2}$ Bert Bolin Centre for Climate Research, Stockholm University, 10691 Stockholm, Sweden \\ ${ }^{3}$ School of Civil and Environmental Engineering, Cornell University, Ithaca, NY 14853-3501, USA
}

Correspondence to: H. E. Dahlke (helen.dahlke@natgeo.su.se)

Received: 20 December 2011 - Published in Hydrol. Earth Syst. Sci. Discuss.: 19 January 2012

Revised: 14 June 2012 - Accepted: 16 June 2012 - Published: 17 July 2012

\begin{abstract}
Our understanding is limited to how transient changes in glacier response to climate warming will influence the catchment hydrology in the Arctic and Sub-Arctic. This understanding is particularly incomplete for flooding extremes because understanding the frequency of such unusual events requires long records of observation not often available for the Arctic and Sub-Arctic. This study presents a statistical analysis of trends in the magnitude and timing of flood extremes and the mean summer discharge in two sub-arctic catchments, Tarfala and Abisko, in northern Sweden. The catchments have different glacier covers (30\% and $1 \%$, respectively). Statistically significant trends (at the $5 \%$ level) were identified for both catchments on an annual and on a seasonal scale (3-months averages) using the MannKendall trend test. Stationarity of flood records was tested by analyzing trends in the flood quantiles, using generalized least squares regression. Hydrologic trends were related to observed changes in the precipitation and air temperature, and were correlated with 3-months averaged climate pattern indices (e.g. North Atlantic oscillation). Both catchments showed a statistically significant increase in the annual mean air temperature over the comparison time period of 1985 2009 (Tarfala and Abisko $p<0.01$ ), but did not show significant trends in the total precipitation (Tarfala $p=0.91$, Abisko $p=0.44$ ). Despite the similar climate evolution over the studied period in the two catchments, data showed contrasting trends in the magnitude and timing of flood peaks and the mean summer discharge. Hydrologic trends indicated an amplification of the streamflow and flood response in the highly glacierized catchment and a dampening of the response in the non-glacierized catchment. The glacierized mountain catch-
\end{abstract}

ment showed a statistically significant increasing trend in the flood magnitudes $(p=0.04)$ that is clearly correlated to the occurrence of extreme precipitation events. It also showed a significant increase in mean summer discharge $(p=0.0002)$, which is significantly correlated to the decrease in glacier mass balance and the increase in air temperature $(p=0.08)$. Conversely, the non-glacierized catchment showed a significant decrease in the mean summer discharge $(p=0.01)$, the flood magnitudes $(p=0.07)$ and an insignificant trend towards earlier flood occurrences $(p=0.53)$. These trends are explained by a reduction of the winter snow pack due to higher temperatures in the winter and spring and an increasing soil water storage capacity or catchment storage due to progressively thawing permafrost.

\section{Introduction}

Recent studies of land-ocean-atmosphere interactions have shown that changes in the global climate are markedly influencing the atmospheric circulation in arctic and sub-arctic regions with direct influences on terrestrial hydrology (Trenberth et al., 2007; Khaliq et al., 2006; Stewart et al., 2005; Jain and Lall, 2001; Cayan et al., 1999). Regional studies of climate change in northern Europe, for example, have found a general increase in the mean annual temperature and annual precipitation (e.g. Moberg et al., 2005; Jansen et al., 2007; Groisman et al., 2005). There has been a corresponding general increase in winter and spring flows (Peterson et al., 2002; Lindström and Bergström, 2004; Wilson et al., 2010) and a general retreat of glaciers in this region (e.g. Jansson 
and Pettersson, 2007; Zemp et al., 2009, Koblet et al., 2010). Changes in glacier area and volume likely alter the streamflow dynamics in the catchment in which they are located by changing both the amount and timing of water released during the melt season (e.g. Fountain and Tangborn, 1985; Röthlisberger and Lang, 1987; Jansson et al., 2003). Thus, the comparative analysis of trends in streamflow records in catchments with differing glacier cover is considered a good indicator to estimate climate-induced shifts in the hydrological cycle of these regions.

Although several studies have focused on the hydrologic effects of climate variability and change, relatively few have examined the interactions between climate variability and change, glacier response and the resulting effects on streamflow (Moore and Demuth, 2001; Abdul-Aziz and Burn, 2006; Burn et al., 2010). Among these hydro-climatological studies there is an emerging body of literature that indicates contrasting hydrologic responses in sub-arctic and arctic catchments to climate variability and change that is depending on the percent glacier cover of a catchment and the glacier state in response to climate (Fleming and Clarke, 2003 and references therein). In glacierized catchments streamflow response to climate warming is a matter of glacier storage. Glacier storage and glacial runoff vary on different time scales in response to climate warming, which can be distinguished as (i) short-term, (ii) intermediate-term, and (iii) long-term storage changes (Jansson et al., 2003). In the shortterm and intermediate-term response to increasing temperatures, glacier runoff will increase while the glacier adjusts its volume to a warmer climate. These storage changes can for example result in prolonged melt seasons, reduced seasonal runoff concentrations and increased diurnal discharge fluctuations (Hock et al., 2005). According to Hock et al. (2005), glacier melt during the short-term response is further amplified by positive feedback mechanisms. For example, enhanced melt water production occurs due to earlier and more extensive disappearance of high-albedo glacial snow and firn. The reduction in firn area and thickness, and greater exposure of low-albedo bare ice will reduce the water retention capacity, allow greater melt, and potentially increase water flow over the glacier surface (Hock et al., 2005). For example, Braun et al. (2000), Box et al. (2005) and Knudsen and Hasholt (2003) reported for different glacierized catchments that streamflow reached greater stream discharges during years with low snow accumulation that lead to extreme glacier ice melting. Knudsen and Hasholt (2003) observed that glacier ablation reached a record high in 1998 in the Mittivakkat glacier catchment in southeast Greenland, despite the lowest mean temperature recorded. This was attributed to the combination of low summer precipitation and low snow coverage on the glacier surface.

In the long-term response of glaciers to climate warming, flow rates will decrease when the glacier volume is adjusting to a new volume-to-area equilibrium or disappearing (e.g. Jansson et al., 2003). Depending on the glacier covered area of a catchment these differences in glacier storage can translate into differences in catchment hydrologic response. For example, recent studies indicate that regardless of differences in inter-annual streamflow, variability catchments at low elevation and/or with low glacier cover show predominantly decreasing streamflow trends (e.g. Dery et al., 2005; Burn et al., 2010), whereas increasing trends are found in catchments located at high elevation and/or with high glacier cover (Casassa et al., 2009). For example, Hodgkins (2009) found that June through August flows increased by $8 \%$ to $11 \%$ for glacierized basins (more than $10 \%$ glacier cover) in southeastern Alaska, USA and decreased by $3 \%$ to $9 \%$ for non-glacierized basins. Similarly, Fleming and Clarke (2003), Stahl and Moore (2006), Fleming et al. (2006) and Pellicciotti et al. (2010) observed increasing mean monthly summer (July-September) and annual streamflows in recent years in several catchments characterized by a greater glacier-covered area in northwestern British Columbia, Canada and the European Alps. Decreasing flow rates due to increased glacier wastage have been, for example, observed in glacierized catchments in southern British Columbia by, among others, Moore and Demuth (2001) and Stahl and Moore (2006). Together these studies elucidate the existence of a glacier coverage threshold that determines the hydrologic response of glacierized catchments to climate change.

Many of the observed increasing trends in summer streamflow in catchments with greater glacier cover are connected to climate variability or changes in climate or both. Most studies attribute the observed changes in streamflows to increasing trends in air temperature (e.g., Fleming and Clarke, 2003; Birsan et al., 2005). However, much of the observed variability in historic streamflow trends is also related to low-frequency climatic forcing and climate pattern indices such as the North Atlantic oscillation (NAO) or the Pacific decadal oscillation (PDO). For example, Fleming et al. (2006) and Hodgkins (2009) observed positive glacial streamflow anomalies in late spring and early summer in years dominated by the positive phase of the PDO and Arctic oscillation (AO), which caused higher air temperatures and increased winter precipitation. Similarly, Birsan et al. (2005) found high correlations between summer streamflow and the NAO index of the previous winter season, which caused increased winter precipitation and subsequently increased spring and summer melt.

However, studies of Woo and Thorne (2008) and Birsan et al. (2005) indicate that despite the fact that climate forcing can impart a strong signal on streamflow response, not all catchments within the same climate forcing show the same observed hydrologic response because factors such as location, topography and storage can overwhelm the climatic influence. On the contrary, temperature and precipitation anomalies caused by climate variability can influence and change the current flow regime and runoff generation mechanisms in a catchment, which could impact the nature of 


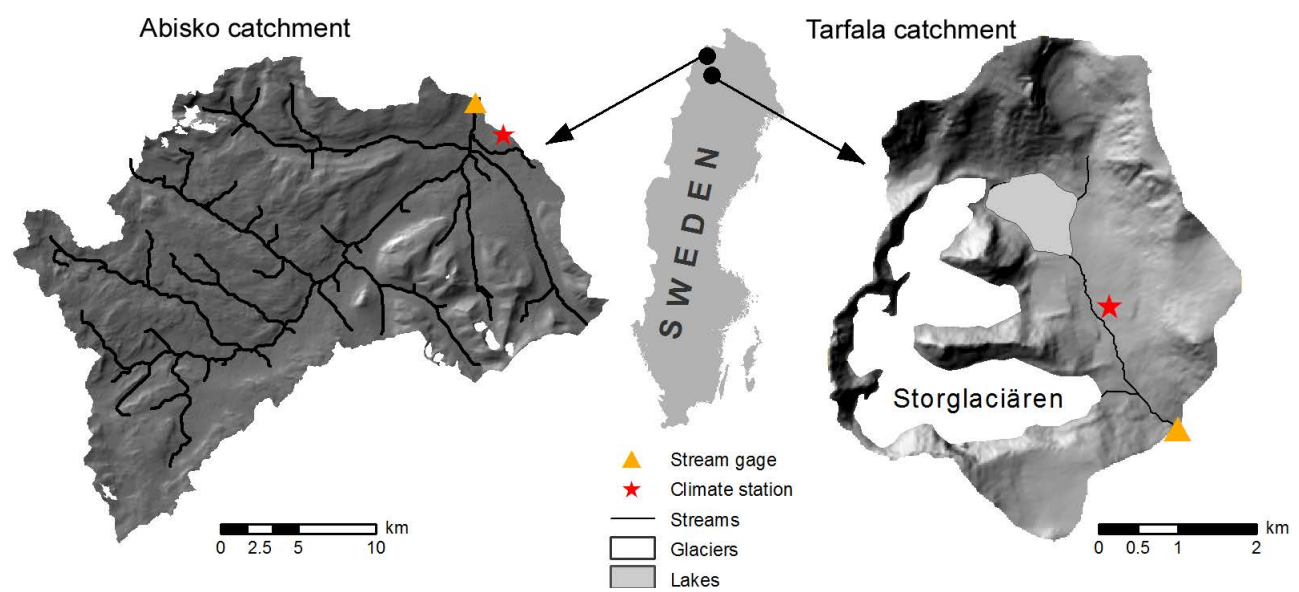

Fig. 1. Site map showing the Abisko and Tarfala catchments in northern Sweden. Triangles and stars indicate locations of stream gauges and rain gauges, respectively. Note the different scales of the catchment maps.

extreme flows, such as flood events. For example, increased winter temperatures can be expected to cause a reduction of the snowpack before the onset of the spring melt, which might lead to a decrease in snowmelt-related flood magnitudes. This may lead to a greater importance of rainfallrunoff flood events, especially if changes occur in the magnitude or intensity of severe rainfall events (Burn et al., 2010). Kane et al. (2003) for example found for the Upper Kuparuk watershed in Alaska that a few high-intensity precipitation events appear to generate greater runoff volumes (three times greater) than a large number of low intensity events. They hypothesized that these minor precipitation events may be important in priming the watershed for the high magnitude events by filling water storages. However, it remains largely unknown how climate induced transient changes in the glacier-covered catchment area and the short-term and intermediate-term glacier storage manifest themselves in the catchment hydrologic response and flood extremes in subarctic and arctic environments.

With the ongoing and expected reduction in global glacier volume, there is a need to better understand how changes associated with the reduction in glacier storage affect glacial melt water runoff and thereby terrestrial hydrology. Assessment of gradual hydrologic change induced by climate and change in the causal flood generating mechanisms in the Arctic and Sub-Arctic is challenging because assessing such events requires long records of observation not often available for these regions. The goal of this study is to test the hydrologic and meteorologic response of two sub-arctic catchments with differing glacier cover in northern Sweden for climate induced trends and potential shifts in the runoff generating mechanisms. For this study the Tarfala catchment (30\% glacierized), in which the largest of four glaciers, Storglaciären, is situated with the longest continuous glacier mass balance record (since 1946) currently available worldwide (e.g. Holmlund et al., 2005; Jansson and Pettersson,
2007), and the upper Abisko catchment (1\% glacierized), which has a continuous $97-y r$ record of meteorological observations, were compared. The hypothesis of this study is that both catchments exhibit similar hydrologic and meteorologic trends to climate warming. To test this hypothesis, statistical trends in the magnitude and timing of floods, the flood quantiles, and the mean summer discharge will be assessed using the Mann-Kendall trend test and generalized least squares regression. In addition, potential links to climate variability and climate change will be identified by relating hydrologic trends to annual and seasonal trends in the minimum, maximum and mean temperature, the maximum and total precipitation and annual and 3-months averaged large-scale climate teleconnection patterns (e.g. Northern Atlantic oscillation, Atlantic multidecadal oscillation).

\section{Methods}

\subsection{Site descriptions}

This study considers two catchments in northern Sweden: the upper Abisko $\left(68^{\circ} 21^{\prime} 36^{\prime \prime} \mathrm{N}, 18^{\circ} 46^{\prime} 48^{\prime \prime} \mathrm{E}\right)$ and the Tarfala $\left(67^{\circ} 53^{\prime} 56^{\prime \prime} \mathrm{N}, 18^{\circ} 37^{\prime} 57^{\prime \prime} \mathrm{E}\right)$ (Fig. 1). Both catchments are characterized by relatively pristine land-use conditions and minimal human influences. The drainage areas of the Abisko and Tarfala catchments are $566 \mathrm{~km}^{2}$ and $21.7 \mathrm{~km}^{2}$, respectively. The stream gauging stations are located at $340 \mathrm{~m}$ (Abisko) and $1091 \mathrm{~m}$ (Tarfala) above sea level. The elevation difference (relief) in these mountainous catchments is large and ranges from 340 to $1800 \mathrm{~m}$ a.s.l. in the Abisko catchment and from 980 to $2100 \mathrm{~m}$ a.s.l. in the Tarfala catchment. Vegetation is found mainly in the valley bottom of both catchments. A mountain birch forest dominates the valley bottom of the Abisko catchment, while alpine heath dominates the Tarfala catchment. Both catchments are located in the 
discontinuous permafrost zone. The glacierized area in the Tarfala and Abisko catchments is $30 \%$ and $1 \%$, respectively.

Regional climate in northern Sweden is cold and humid. Annual precipitation amounts are determined by topography and dominant weather patterns. Thus, mean annual precipitation amounts in the Abisko catchment range from approximately $300 \mathrm{~mm} \mathrm{yr}^{-1}$ as recorded at the Abisko Scientific Research Station $\left(68^{\circ} 21^{\prime} \mathrm{N}, 18^{\circ} 49^{\prime} \mathrm{E}, 385 \mathrm{~m}\right.$ a.s.l. $)$ to over $900 \mathrm{~mm} \mathrm{yr}^{-1}$ in the peak areas of the catchment (1913-1990) (Josefsson, 1990; Alexandersson et al., 1991). In the Tarfala catchment the mean annual precipitation measured at the Tarfala Research Station $\left(67^{\circ} 55^{\prime} \mathrm{N}, 18^{\circ} 37^{\prime} \mathrm{E}, 1135 \mathrm{~m}\right.$ a.s.l. $)$ has been estimated to be $1997 \pm 450 \mathrm{~mm}$, of which approximately $400-600 \mathrm{~mm}$ fall between June and August. This annual precipitation amount represents an estimate based on the winter mass balance of Storglaciären (i.e. the average amount of precipitation (in $\mathrm{m}$ water equivalent) deposited as snow onto the glacier between mid-September and mid-April) and measurements of liquid precipitation at the Tarfala Research Station during the summer season (excluding precipitation measurements on days with a daily average temperature less than $0^{\circ} \mathrm{C}$ ) for the period 1980-2009. The mean annual air temperature in the Abisko and Tarfala catchment is $-0.5 \pm 1.0^{\circ} \mathrm{C}$ (1913-2009) and $-3.4 \pm 1.0^{\circ} \mathrm{C}$ (1965-2009), respectively.

\subsection{Data}

\subsubsection{Hydrometric data}

Our analysis is based on long-term daily precipitation and temperature data available for the Abisko catchment for the time period 1913-2009, and daily streamflow data from the period 1919-2009. Precipitation and temperature data for the Abisko catchment are available from the Abisko Scientific Research Station and streamflow data are available from the Swedish Meteorological and Hydrological Institute (SMHI) (gauge ID 957). Streamflow in the Abisko catchment was not monitored for the period 1956-1985. There were, however, no changes in the stream gauge location or the stage-discharge relationship between the time period before (1919-1956) and after (1985-2009) this period when monitoring was discontinued. Daily temperature data for the Tarfala catchment were available from 1965-2009, daily data of liquid precipitation (available for June through September) were available for the period 1980-2009, and daily streamflow data (available for mid-May through September) were available for the period 1969-2009. Streamflow, precipitation and temperature data are available through the Tarfala Research Station (http://tarfalawiki.natgeo.su.se/tarfalawiki/ index.php/Main_Page).

\subsubsection{Glacier mass balance data}

For the Tarfala catchment continuous long-term mass balance data are available through the TRS for the $2.9 \mathrm{~km}^{2}$ Stor- glaciären glacier $\left(65^{\circ} 55^{\prime} \mathrm{N}, 18^{\circ} 35^{\prime} \mathrm{E}\right)$ occupying the southwestern part of the catchment at an elevation range of 1130 to $1700 \mathrm{~m}$ a.s.l. Storglaciären is described as a polythermal glacier with a perennial cold surface layer in the ablation area (e.g. Pettersson et al., 2003). Time series data of Storglaciären's glacier mass balance, including volume and area estimates and changes, have been published by, among others, Holmlund et al. (2005: Fig. 3), Jansson and Pettersson (2007), and most recently Zemp et al. (2009: Fig. 3) (for the period 1946-2007) and Koblet et al. (2010). Using definitions by Cogley et al. (2011), estimates of the annual winter $\left(c_{\mathrm{W}}\right)$, summer $\left(a_{\mathrm{s}}\right)$, net balance $\left(b_{\mathrm{n}}\right)$ in $\mathrm{m}$ water equivalent ( $\mathrm{m}$ w.e.), the equilibrium line altitude (ELA) in $\mathrm{m}$ above sea level, and the accumulation area ratio (AAR) were used in this study. The mass balance estimates are area specific estimates. According to Koblet et al. (2010), the surface area of Storglaciären changed very little over the hydrological observation period (approximately $4 \%$ since 1969). This change in area translates into an uncertainty in the annual mass balance estimates of less than $0.1 \mathrm{~m}$ w.e. (Holmlund et al., 2005).

\subsubsection{Climate teleconnection pattern data}

The climate in Europe and Fennoscandia is largely influenced by the interannual and interdecadal oscillations in the atmospheric circulation over the North Atlantic Ocean. These oscillations are quantitatively described by climate indices, also called teleconnection pattern indices, which are calculated from the 700-hPa geopotential heights (e.g. Climate Diagnostics Bulletin, 2001; Panagiotopolous et al., 2002; Barnston and Livezey, 1987). For the AtlanticEuropean region, Nesterov (2009) listed several important climate patterns and their indices that control the cyclone trajectories (storm tracks) over the North Atlantic and, thus, the temperature and precipitation anomalies over Europe and Fennoscandia. These indices are the North Atlantic oscillation (NAO) index (Barnston and Livezey, 1987), the east Atlantic pattern (EA) index, the East Atlantic-western Russia pattern (EA/WR) index; the Scandinavia pattern (SCA) index, and the Polar-Eurasia pattern (POL) index (Panagiotopoulos et al., 2002; Nesterov, 2009) (Table 1). These climate pattern indices were selected to evaluate the influence of climate on the hydrology in the Tarfala and Abisko catchments. In addition to these teleconnection pattern indices, the Atlantic multidecadal oscillation (AMO) index (Enfield et al., 2001) was included in the analysis, which is a principal expression of the sea surface temperature of the Atlantic Ocean that influences the heat fluxes from the ocean to the atmosphere and thus the transport of moist air masses to highlatitude regions (Enfield et al., 2001). 
Table 1. Summary of climate pattern indices considered in this study and their relationship to temperature and precipitation anomalies in Northern Europe exemplified for the positive phase of the climate pattern indices. The monthly averaged climate index data were acquired for the period 1950-2009 from the sources specified below.

\begin{tabular}{|c|c|c|c|}
\hline Climate index & Temperature (positive phase) & Precipitation (positive phase) & Data source and references \\
\hline $\begin{array}{l}\text { Atlantic multidecadal } \\
\text { oscillation (AMO) }\end{array}$ & $\begin{array}{l}\text { - above-average temperatures } \\
\text { across Scandinavia especially } \\
\text { during the summer }\end{array}$ & $\begin{array}{l}\text { - above-average precipitation } \\
\text { across northern Europe and } \\
\text { Fennoscandia }\end{array}$ & $\begin{array}{l}\text { http://www.esrl.noaa.gov/psd/data/ } \\
\text { correlation/amon.us.data } \\
\text { Enfield et al. (2001); Arguez et } \\
\text { al. (2009); Sutton and Hodson (2005) }\end{array}$ \\
\hline $\begin{array}{l}\text { East Atlantic/Western } \\
\text { Russia (EA/WR) }\end{array}$ & $\begin{array}{l}\text { - below-average tempera- } \\
\text { tures across northeastern } \\
\text { Fennoscandia }\end{array}$ & $\begin{array}{l}\text { - above-average precipitation } \\
\text { across northern Fennoscandia }\end{array}$ & $\begin{array}{l}\text { http://www.cpc.ncep.noaa.gov/data/ } \\
\text { teledoc/eawruss.shtml } \\
\text { Barnston and Livezey et al. (1987); Ar- } \\
\text { guez et al. (2009) }\end{array}$ \\
\hline East Atlantic (EA) & - no clear effect & $\begin{array}{l}\text { - above-average precipitation } \\
\text { across northern Europe and } \\
\text { Fennoscandia }\end{array}$ & $\begin{array}{l}\text { http://www.cpc.ncep.noaa.gov/data/ } \\
\text { teledoc/ea.shtml } \\
\text { Panagiotopoulos et al. (2002); Nes- } \\
\text { terov (2009) }\end{array}$ \\
\hline $\begin{array}{l}\text { North Atlantic } \\
\text { oscillation (NAO) }\end{array}$ & $\begin{array}{l}\text { - above-average temperatures } \\
\text { across Fennoscandia }\end{array}$ & $\begin{array}{l}\text { - above-average winter pre- } \\
\text { cipitation and below-average } \\
\text { summer precipitation across } \\
\text { Fennoscandia }\end{array}$ & $\begin{array}{l}\text { http://www.cpc.ncep.noaa.gov/data/ } \\
\text { teledoc/nao.shtml } \\
\text { Panagiotopoulos et al. (2002); Nes- } \\
\text { terov (2009) }\end{array}$ \\
\hline Polar/Eurasia (POL) & - no clear effect & $\begin{array}{l}\text { - above-average precipitation } \\
\text { across polar regions north of } \\
\text { Fennoscandia }\end{array}$ & $\begin{array}{l}\text { http://www.cpc.ncep.noaa.gov/data/ } \\
\text { teledoc/poleur.shtml } \\
\text { Panagiotopoulos et al. (2002) }\end{array}$ \\
\hline $\begin{array}{l}\text { Scandinavia pattern } \\
\text { (SCAND) }\end{array}$ & $\begin{array}{l}\text { - above-average temperatures } \\
\text { across Fennoscandia }\end{array}$ & $\begin{array}{l}\text { - below-average precipitation } \\
\text { across Fennoscandia }\end{array}$ & $\begin{array}{l}\text { http://www.cpc.ncep.noaa.gov/data/ } \\
\text { teledoc/scand.shtml } \\
\text { Panagiotopoulos et al. (2002) }\end{array}$ \\
\hline
\end{tabular}

\subsection{Statistical methods}

\subsubsection{Trend statistics and correlations}

The nonparametric Mann-Kendall (MK) trend test (Kendall, 1975; Helsel and Hirsch, 1992; Douglas et al., 2000) was used to investigate trends in the time series data available for both catchments. The test is based on the assumption that time series data are independent and identically distributed and not auto-correlated (Helsel and Hirsch, 1992; Douglas et al., 2000). The MK trend test determines whether a time series exhibits a monotonic trend without specifying whether the trend is linear or nonlinear.

For each catchment the MK trend test was performed to assess the degree of non-stationarity in the annual series and series for 3-month seasons (i.e., December through February [DJF] defines winter; March through May [MAM] defines spring; June through August [JJA] defines summer; September through November [SON] defines autumn) temperature and precipitation data. For the annual and months groupings, the length of each time series corresponded to the number of years of data available. For all groupings, trends in the minimum, mean, and maximum temperature values, and the total and maximum precipitation values were determined. In addition trends in the maximum daily flow (flood magnitude), the date of maximum daily flow (flood occurrence), and the mean summer flows were assessed for both catchments using the MK trend test. The date of flood occurrence is denoted by the day of the year (DOY). For each data set the MK trend test was performed with a significance level of $5 \%$ (2-sided). In addition, linear regressions were fit to the time series data to determine approximate rates of change. In this study trends were estimated for the maximum record period available for each catchment as well as for overlapping time windows to allow direct comparison of the observed trends between the two catchments. Trends were also estimated for the common time windows for which observations from both catchments were available covering the period 1965-2009 for temperature records, 1980-2009 for precipitation records and 1985-2009 for discharge records. In addition, trends were estimated for the 1985-2009 period representing the longest record period possible for which temperature, precipitation and discharge data from both catchments were available.

To identify whether flood events in each catchment were predominantly associated with precipitation events or high temperature periods (and subsequent snowmelt), the flood DOY was compared to the DOY of the daily annual maximum precipitation and the mean daily air temperature for each record year. In addition, the flood DOY was compared to the median DOY of a 3-day period with maximum observed daily precipitation amounts and mean air temperatures. 
Table 2. Summary of the Mann-Kendall (MK) trend test statistics of annual and seasonal temperature and precipitation trends for the common time period of 1985-2009 for the Tarfala and Abisko catchments. Trend significance of the MK trend test is indicated by the 2-sided $p$-value and trends significant at the $5 \%$ level are highlighted in bold. Linear change rates and the type of change (i.e., increasing (positive values), decreasing (negative values)) were estimated from the slope of a linear regression fitted to the data.

\begin{tabular}{|c|c|c|c|c|c|c|c|c|c|c|}
\hline & \multicolumn{6}{|c|}{ Temperature } & \multicolumn{4}{|c|}{ Precipitation } \\
\hline & \multicolumn{6}{|c|}{ Tarfala } & \multicolumn{4}{|c|}{ Tarfala } \\
\hline \multirow[t]{2}{*}{ Analysis period } & \multicolumn{3}{|c|}{$\begin{array}{c}\text { MK trend test } \\
\text { (2-sided } p \text {-value) }\end{array}$} & \multicolumn{3}{|c|}{$\begin{array}{l}\text { Linear change rate } \\
\left({ }^{\circ} \mathrm{C} \text { decade }^{-1}\right)\end{array}$} & \multicolumn{2}{|c|}{$\begin{array}{c}\text { MK trend test } \\
\text { (2-sided } p \text {-value) }\end{array}$} & \multicolumn{2}{|c|}{$\begin{array}{l}\text { Linear change rate } \\
\left(\mathrm{mm} \text { decade }^{-1}\right)\end{array}$} \\
\hline & $\min$ & mean & $\max$ & $\min$ & mean & $\max$ & $\max$ & total & $\max$ & total \\
\hline Annual & 0.18 & $<\mathbf{0 . 0 1}$ & $<\mathbf{0 . 0 1}$ & 1.60 & 0.96 & 1.16 & & & & \\
\hline MAM & 0.16 & 0.28 & 0.43 & 1.34 & 0.63 & 0.57 & & & & \\
\hline JJA & 0.32 & $<0.01$ & $<0.01$ & -0.42 & 0.72 & 1.16 & 0.29 & 0.91 & 5.76 & 4.72 \\
\hline SON & 0.82 & 0.15 & $<\mathbf{0 . 0 1}$ & 0.43 & 0.68 & 1.48 & & & & \\
\hline \multirow[t]{2}{*}{ DJF } & 0.06 & $<0.01$ & 0.12 & 2.65 & 1.41 & 0.80 & & & & \\
\hline & \multicolumn{6}{|c|}{ Abisko } & \multicolumn{4}{|c|}{ Abisko } \\
\hline Annual & 0.47 & $<0.01$ & 0.91 & 0.95 & 0.67 & 0.10 & 0.09 & 0.44 & 3.55 & 9.18 \\
\hline MAM & 0.98 & 0.20 & 0.07 & -0.94 & 0.65 & 0.99 & 0.70 & 0.76 & 0.56 & 1.65 \\
\hline JJA & 0.10 & 0.05 & 0.90 & 0.61 & 0.52 & 0.10 & 0.15 & 0.09 & 4.02 & 18.75 \\
\hline SON & 0.37 & 0.39 & 0.19 & 0.77 & 0.36 & 0.56 & 0.56 & 0.98 & 0.33 & -1.37 \\
\hline DJF & 0.48 & 0.69 & 0.09 & 1.34 & 0.52 & 0.83 & 0.35 & 0.47 & -1.61 & -13.51 \\
\hline
\end{tabular}

For each catchment a joint analysis of climate pattern indices (Table 1), flood records and the mean summer (JJA) discharge was performed. Pairwise correlations between the logarithms of the maximum annual discharge, the day of the flood peaks, the mean summer discharge and seasonally (3months averages over the winter, spring and summer season) and annually (12-months) averaged climate pattern indices were calculated. In addition, for the Tarfala catchment flood records and the mean summer discharge were correlated to $c_{\mathrm{W}}, a_{\mathrm{s}}$, and $b_{\mathrm{n}}$ of Storglaciären. This analysis sought to assess both the response of the catchment hydrology to climate and the effect of glaciers on long-term streamflow variations in each catchment.

\subsubsection{Flood frequency analysis}

The extreme value type I distribution, also known as the Gumbel distribution, was fit to all flood peaks for both the Tarfala and Abisko catchments using the maximum likelihood method (Gumbel, 1958; Jenkinson, 1969). This was done to estimate the exceedance probability of a certain flood event based on the full flood record. Model adequacy of the fitted distribution was tested with a probability plot correlation test (Vogel, 1987). In order to explore how the annual flood extremes have varied over time, flood quantiles (computed from the 1969-2009 record) were tested for stationarity by estimating trends in the time-varying probability of exceedance of selected flood percentiles using a 10-yr moving window. The key flood percentiles considered are the 50th, 90th, 95th, and 99th percentiles of the data computed with the Gumbel distribution from the full 45-yr record. These percentiles correspond to floods with return periods of 2,10 , 20 , and $100 \mathrm{yr}$, respectively. The time-varying, moving window probability of exceedance of each key percentile is estimated by fitting the Gumbel distribution to all flood records within the moving window. For these 10-yr moving window estimates model adequacy of the fitted Gumbel distribution was likewise tested using the probability plot correlation test (Vogel, 1987). Finally, trends in these key flood percentiles versus calendar year were estimated by fitting a generalized least squares regression using a maximum likelihood estimator. An autoregressive polynomial of the $\operatorname{ARMA}(2,0)$ structure is fit to the errors in the GLS model to account for the autocorrelation in the residuals of the time-varying, moving window flood percentiles (Fox and Hartnagel, 1979). Autocorrelation in the time-varying, moving window flood percentiles was estimated using the Durbin-Watson test (Durbin and Watson, 1950). A general pattern of the autocorrelation and partial autocorrelation functions in the shape of a sinusoidal decay with two spikes (one positive, the other negative) is suggestive of an AR2 process, which means that only an autoregressive model is fit to the data (Chatfield, 1989).

\section{Results}

\subsection{Temperature and precipitation trends}

The most prevalent trends found in the Abisko and Tarfala catchment data for the comparison period of 1985-2009 


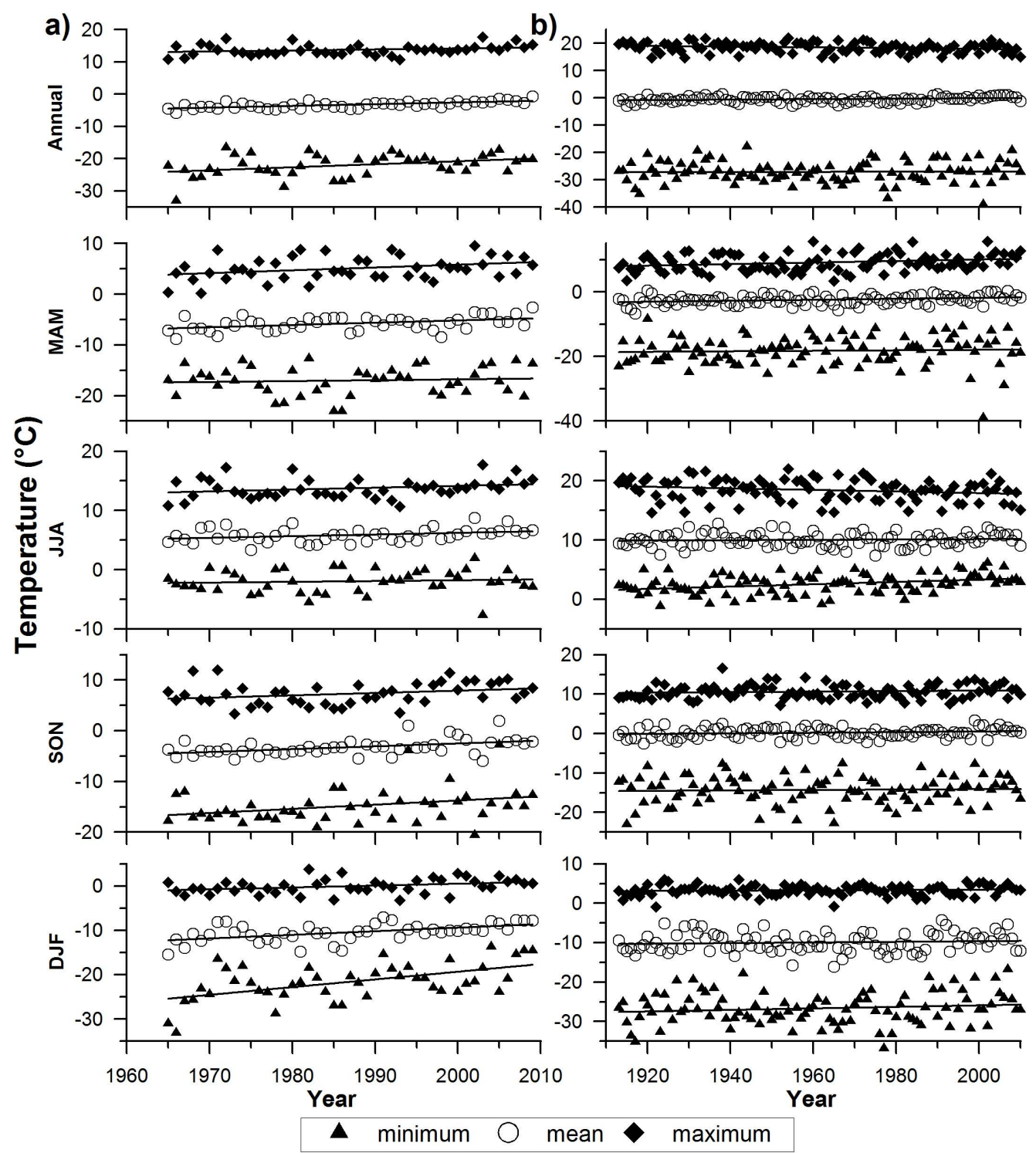

Fig. 2. Time series of annual and seasonal air temperatures $\left({ }^{\circ} \mathrm{C}\right)$ for (a) Tarfala and (b) Abisko catchments. The maximum, mean and minimum annual and seasonal temperatures are indicated by a filled diamond, open circle and filled triangle respectively. Black lines indicate linear regressions versus time. Linear change rates and MK trend statistics are presented in Tables 2 and 3.

comprise a significant increase in the mean annual and mean summer (JJA) air temperature, respectively (Table 2, Fig. 2). In this period, the mean annual air temperature increased at a rate of $0.67^{\circ} \mathrm{C}$ decade $^{-1}$ and $0.96^{\circ} \mathrm{C}$ decade $^{-1}$ in the Abisko and Tarfala catchments, respectively (Table 2). When comparing temperature trends in the Abisko and Tarfala catchments for the maximum record available for the Tarfala catchment (1965-2009), trends towards higher mean annual and seasonal air temperatures were persistently found in both catchments (Tables 2, 3 and 4). During this period the annual mean air temperature increased at a similar rate of $0.46^{\circ} \mathrm{C}$ decade $^{-1}$ and $0.54^{\circ} \mathrm{C}$ decade $^{-1}$ respectively in the Abisko and Tarfala catchment (Tables 3 and
4). In both catchments, winter (DJF) saw the largest while summer (JJA) saw the smallest mean temperature rise (Tables 3 and 4). During the 1965-2009 period spring warming has increased at a similar rate in both catchments. However, in the Tarfala catchment the mean autumn (SON) temperature was increasing at a greater rate $\left(0.56^{\circ} \mathrm{C}\right.$ decade $\left.^{-1}\right)$ than the spring temperature $\left(0.45^{\circ} \mathrm{C}\right.$ decade $\left.^{-1}\right)$ (Tables 2, 3 and 4). The MK trend test performed for the full temperature record available for the Abisko catchment (1913-2009) show significant $(p<0.05)$ increasing trends in the mean and maximum spring (MAM) temperature, and a significant decrease in the daily temperature range observed during summer (JJA), which can be attributed to a significant increase in 
Table 3. Mann-Kendall (MK) trend test statistics on the maximum available time series data of annual and seasonal precipitation (19802009) and temperature (1965-2009) for the Tarfala catchment. Trend significance of the MK trend test is indicated by the 2-sided $p$-value and trends significant at the $5 \%$ level are highlighted in bold. Linear change rates and the type of change (i.e., increasing (positive values), decreasing (negative values)) were estimated from the slope of a linear regression fitted to the data.

\begin{tabular}{|c|c|c|c|c|c|c|c|c|c|c|}
\hline \multirow{3}{*}{ Time period } & \multicolumn{6}{|c|}{ Temperature (1965-2009) } & \multicolumn{4}{|c|}{ Precipitation (1980-2009) } \\
\hline & \multicolumn{3}{|c|}{$\begin{array}{c}\text { MK trend test } \\
(p \text {-value })\end{array}$} & \multicolumn{3}{|c|}{ 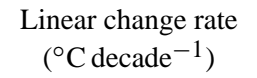 } & \multicolumn{2}{|c|}{$\begin{array}{c}\text { MK trend test } \\
(p \text {-value })\end{array}$} & \multicolumn{2}{|c|}{$\begin{array}{l}\text { Linear change rate } \\
\left(\mathrm{mm} \mathrm{decade}^{-1}\right)\end{array}$} \\
\hline & $\min$ & mean & $\max$ & $\min$ & mean & $\max$ & $\max$ & total & $\max$ & total \\
\hline Annual & 0.04 & $<\mathbf{0 . 0 1}$ & 0.04 & 0.93 & 0.54 & 0.31 & & & & \\
\hline MAM & 0.61 & 0.01 & 0.06 & 0.17 & 0.45 & 0.56 & & & & \\
\hline JJA & 0.52 & 0.01 & $\mathbf{0 . 0 3}$ & 0.13 & 0.28 & 0.31 & 0.32 & 0.56 & 4.31 & 21.03 \\
\hline SON & 0.04 & $<\mathbf{0 . 0 1}$ & 0.02 & 0.82 & 0.56 & 0.47 & & & & \\
\hline DJF & $<0.01$ & $<\mathbf{0 . 0 1}$ & 0.02 & 1.74 & 0.82 & 0.43 & & & & \\
\hline
\end{tabular}

Table 4. Mann-Kendall (MK) trend test statistics on the maximum available time series data of annual and seasonal precipitation and temperature data (1913-2009) (upper table). The lower table shows MK trend statistics for time periods where both temperature (19652009) and precipitation data (1980-2009) from the Abisko and Tarfala catchment were available. Trend significance of the MK trend test is indicated by the 2 -sided $p$-value and trends significant at the $5 \%$ level are highlighted in bold. Linear change rates and the type of change (i.e., increasing (positive values), decreasing (negative values)) were estimated from the slope of a linear regression fitted to the data.

\begin{tabular}{|c|c|c|c|c|c|c|c|c|c|c|}
\hline \multirow{4}{*}{ Analysis period } & \multicolumn{6}{|c|}{ Temperature } & \multicolumn{4}{|c|}{ Precipitation } \\
\hline & \multicolumn{6}{|c|}{ Long-term trend (1913-2009) } & \multicolumn{4}{|c|}{ Long-term trend (1913-2009) } \\
\hline & \multicolumn{3}{|c|}{$\begin{array}{c}\text { MK trend test } \\
\text { (2-sided } p \text {-value) }\end{array}$} & \multicolumn{3}{|c|}{$\begin{array}{l}\text { Linear change rate } \\
\qquad\left({ }^{\circ} \mathrm{C} \text { decade }{ }^{-1}\right)\end{array}$} & \multicolumn{2}{|c|}{$\begin{array}{c}\text { MK trend test } \\
\text { (2-sided } p \text {-value) }\end{array}$} & \multicolumn{2}{|c|}{$\begin{array}{l}\text { Linear change rate } \\
\left(\mathrm{mm} \text { decade }^{-1}\right)\end{array}$} \\
\hline & $\min$ & mean & $\max$ & $\min$ & mean & $\max$ & $\max$ & total & $\max$ & total \\
\hline Annual & 0.87 & 0.01 & $\mathbf{0 . 0 2}$ & 0.02 & 0.09 & -0.14 & 0.64 & $\mathbf{0 . 0 1}$ & 0.35 & 4.70 \\
\hline MAM & 0.11 & 0.01 & $\mathbf{0 . 0 2}$ & 0.08 & 0.15 & 0.23 & 0.13 & 0.67 & -0.17 & 0.07 \\
\hline JJA & $<\mathbf{0 . 0 1}$ & 0.40 & $\mathbf{0 . 0 2}$ & 0.20 & 0.03 & -0.13 & 0.38 & 0.21 & 0.49 & 1.80 \\
\hline SON & 0.74 & 0.10 & 0.14 & 0.05 & 0.08 & 0.07 & 0.81 & 0.52 & -0.02 & 0.94 \\
\hline \multirow[t]{2}{*}{ DJF } & 0.27 & 0.37 & 0.36 & 0.19 & 0.08 & 0.04 & 0.15 & 0.06 & 0.22 & 1.70 \\
\hline & \multicolumn{6}{|c|}{$\begin{array}{l}\text { Longest overlapping time period } \\
\qquad(1965-2009)\end{array}$} & \multicolumn{4}{|c|}{$\begin{array}{l}\text { Longest overlapping time period } \\
\qquad(1980-2009)\end{array}$} \\
\hline Annual & 0.13 & $<\mathbf{0 . 0 1}$ & 0.38 & 0.63 & 0.46 & -0.16 & 0.87 & 0.95 & 0.16 & -5.59 \\
\hline MAM & 0.59 & 0.01 & 0.08 & -0.16 & 0.47 & 0.55 & 0.63 & 0.45 & 0.46 & 3.22 \\
\hline JJA & 0.04 & 0.04 & 0.38 & -0.34 & 0.26 & -0.16 & 0.83 & 0.94 & 0.25 & -2.14 \\
\hline SON & 0.23 & $<\mathbf{0 . 0 1}$ & 0.16 & 0.42 & 0.34 & 0.25 & 0.91 & 0.89 & -0.91 & 0.36 \\
\hline DJF & 0.03 & 0.02 & 0.28 & 1.18 & 0.76 & 0.24 & 0.02 & 0.15 & -2.73 & -10.37 \\
\hline
\end{tabular}

the minimum summer temperature and a significant decrease in the maximum summer temperature (Table 4). During this period, spring saw the largest $\left(0.15^{\circ} \mathrm{C}\right.$ decade $\left.^{-1}\right)$ and summer the smallest $\left(0.03{ }^{\circ} \mathrm{C} \mathrm{decade}^{-1}\right)$ mean temperature rise in the Abisko catchment.

Over the comparison period of 1985-2009 both Abisko and Tarfala showed no significant trends in the annual and seasonal, total and maximum precipitation data. When comparing precipitation trends in the Abisko and Tarfala catchment for the maximum record available for the Tarfala catchment (1980-2009), no clear trends in the annual or seasonal maximum and total precipitation amounts were found, with exception of a significant decrease in the maximum winter (DJF) precipitation in the Abisko catchment, which decreased at a rate of $10.4 \mathrm{~mm} \mathrm{decade}^{-1}$ since $1980(p=0.02)$ (Table 4). The annual precipitation in the Abisko catchment showed, however, a significant $(p=0.01)$ increasing trend over the full record period of 1913-2009 (Fig. 3, Table 4). The largest contributor to this increase in the total annual precipitation was the winter (DJF) precipitation, which increased since 1913 at a rate of $1.7 \mathrm{~mm} \mathrm{decade}^{-1}$ $(p=0.06)$. In contrast, the maximum and total precipitation of the spring, summer and autumn seasons remained relatively constant over the 97-yr record period (Table 4). In 
Table 5. $P$-values of non-stationarity test on selected percentiles (50th, 90th, 95th, 98th, and 99th) of the annual maximum discharge data of the Tarfala and Abisko catchments. The percentiles were estimated by performing a moving window analysis with a 10-yr window. Nonstationarity was estimated at a significance level of $5 \%$ by performing a trend analysis on the quantiles using a generalized least squares regression model. 2-sided $p$-values smaller than 0.05 and highlighted in bold indicate that the selected quantiles exhibited non-stationarity.

\begin{tabular}{cc|cc|cc}
\hline & \multicolumn{2}{|c|}{ Tarfala } & \multicolumn{2}{c}{ Abisko } \\
\hline $\begin{array}{c}\text { Annual Exceedance } \\
\text { probability }\end{array}$ & $\begin{array}{c}\text { Return period of } \\
\text { flood (years) }\end{array}$ & $\begin{array}{c}\text { Long-term } \\
(1969-2009)\end{array}$ & $\begin{array}{c}\text { Common time period } \\
(1985-2009)\end{array}$ & $\begin{array}{c}\text { Long-term } \\
(1919-2009)\end{array}$ & $\begin{array}{c}\text { Common time period } \\
(1985-2009)\end{array}$ \\
\hline 0.5 & 2 & $<\mathbf{0 . 0 1}$ & $<\mathbf{0 . 0 1}$ & $\mathbf{0 . 0 2}$ & $<\mathbf{0 . 0 1}$ \\
0.1 & 10 & $<\mathbf{0 . 0 1}$ & $<\mathbf{0 . 0 1}$ & $\mathbf{0 . 0 2}$ & $<\mathbf{0 . 0 1}$ \\
0.05 & 20 & $<\mathbf{0 . 0 1}$ & $<\mathbf{0 . 0 1}$ & $<.01$ & $<\mathbf{0 . 0 1}$ \\
0.02 & 50 & $<\mathbf{0 . 0 1}$ & $<\mathbf{0 . 0 1}$ & $<\mathbf{0 . 0 1}$ & $<\mathbf{0 . 0 1}$ \\
0.01 & 100 & $<\mathbf{0 . 0 1}$ & $<\mathbf{0 . 0 1}$ & & $<1$ \\
\hline
\end{tabular}
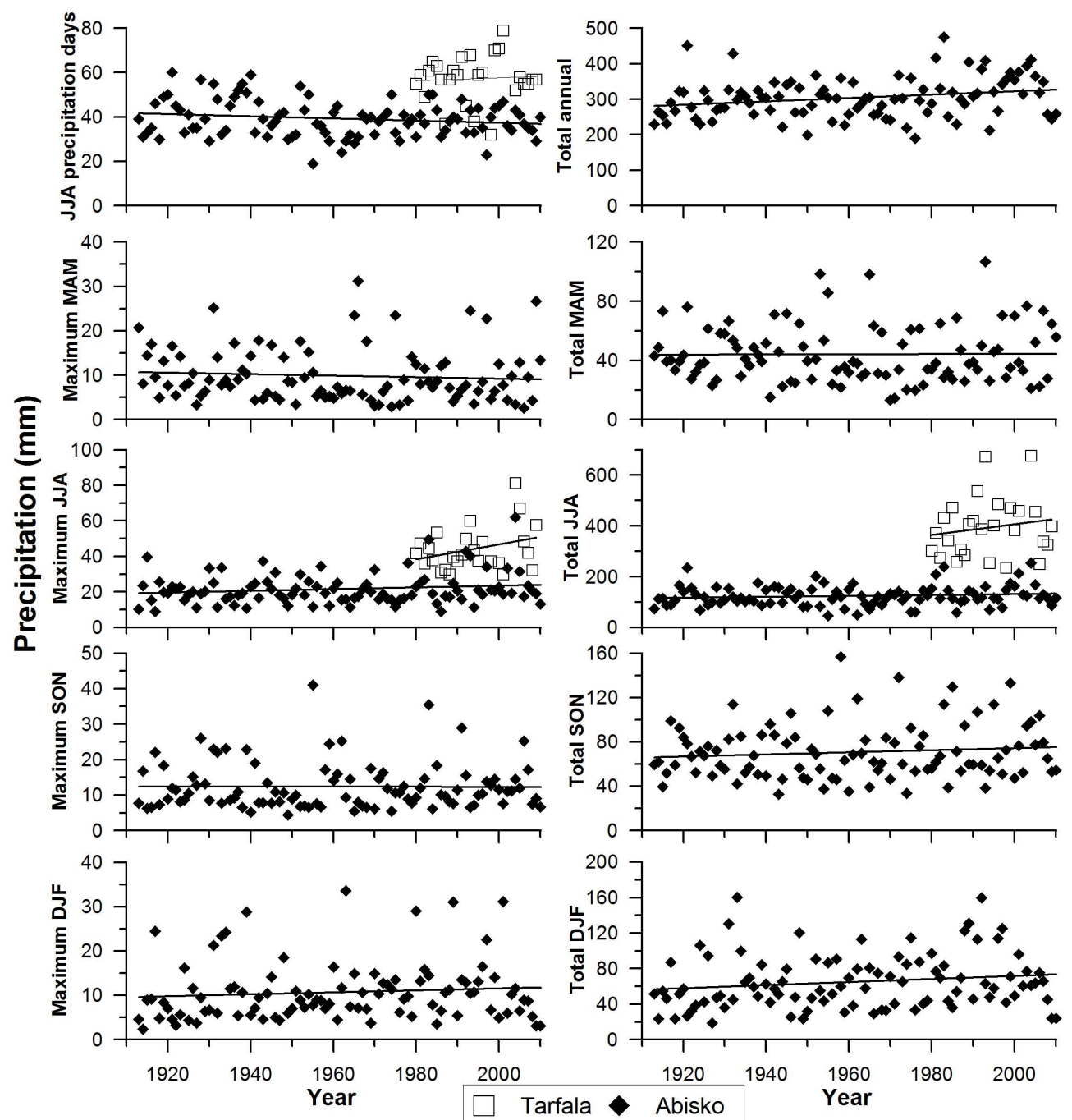

Fig. 3. Time series of annual and seasonal maximum and total precipitation amounts ( $\mathrm{mm}$ ) for the Tarfala (open squares) and Abisko (filled diamonds) catchment. The top left graph shows the number of days with precipitation for the summer (JJA) season. Black lines indicate linear regressions versus time. Linear change rates and MK trend statistics for the long-term record periods and common time windows are presented in Tables 2 and 3. 

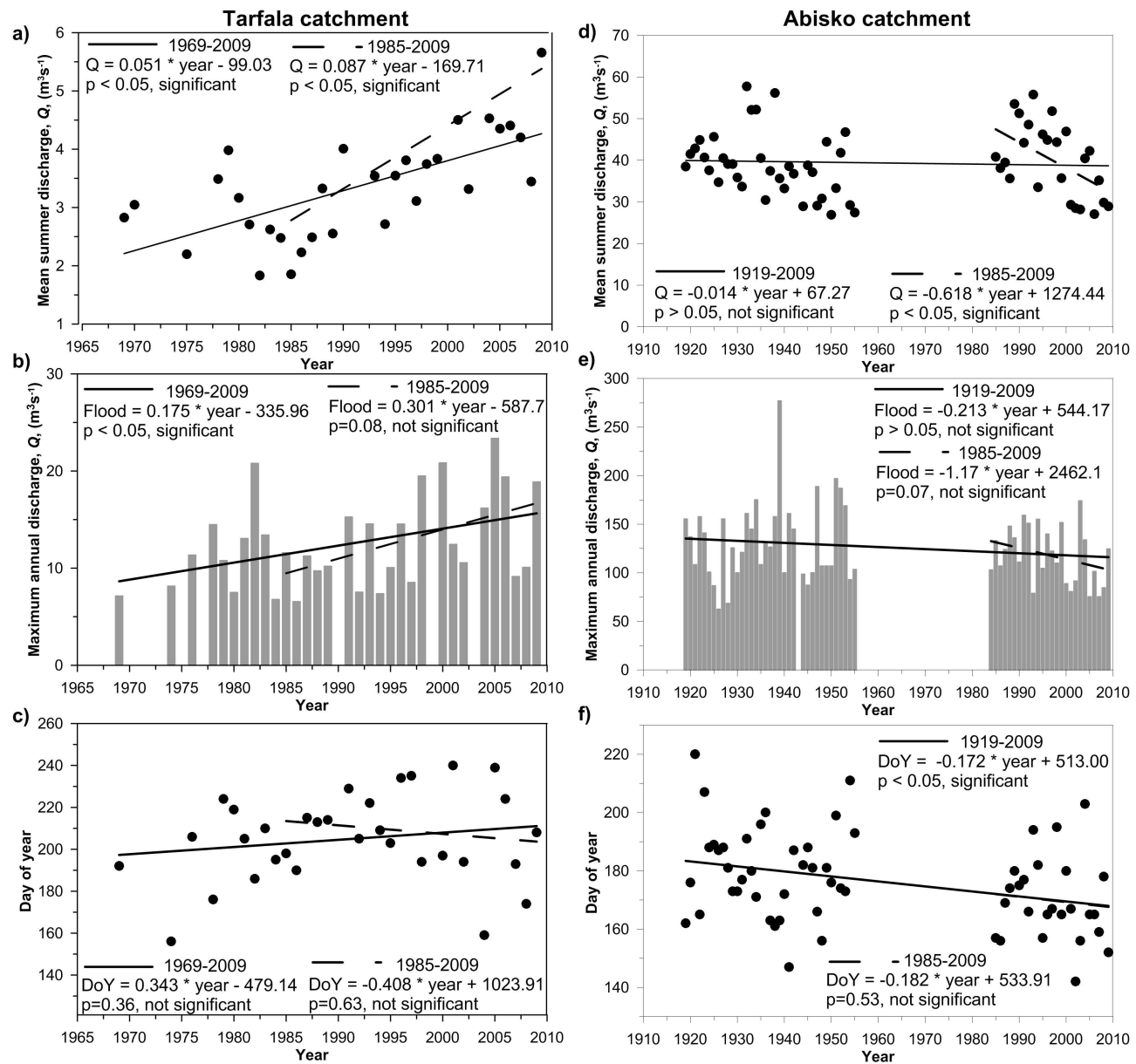

Fig. 4. Statistical characteristics of the Tarfala and Abisko discharge. (a), (d) Time series of mean summer (JJA) discharge; (b), (e) time series of the annual maximum discharge (floods); and (c), (f) time series of the flood occurrence date of annual maximum flood events in the Tarfala and Abisko catchments, respectively. The solid lines represent linear trends over the full record period in each catchment. The dashed lines represent linear trends for the common time period 1985-2009 for which discharge records were available in both catchments.

addition, the variability in extreme precipitation and the magnitude of outliers ("extremes of extremes") has increased in both catchments over each record period. An extreme precipitation event in the Abisko catchment in 1915 equaled $39.7 \mathrm{~mm} \mathrm{~d}^{-1}$. Since that time, the number of years per decade with precipitation amounts exceeding $25 \mathrm{~mm} \mathrm{~d}^{-1}$ has doubled in the Abisko catchment. Similarly, precipitation extremes in the Tarfala catchment have risen from $42 \mathrm{~mm} \mathrm{~d}^{-1}$ in 1980 to $81 \mathrm{~mm} \mathrm{~d}^{-1}$ in 2004. However, in contrast to the changes in precipitation magnitude in both catchments, the summer precipitation frequency (i.e. number of precipitation days in JJA) remained unchanged in both catchments (Fig. 3).

\subsection{Mean discharge and hydrologic extremes}

\subsubsection{Trends}

The Tarfala showed a significant $(p=0.0002)$ increasing trend in the mean summer (JJA) discharge corresponding to an increase of approximately $0.9 \mathrm{~m}^{3} \mathrm{~s}^{-1}$ decade $^{-1}$ over the comparison period (1985-2009) (Fig. 4a). In addition, the maximum annual discharge events of Tarfala have shown a significant increasing trend $(p=0.04)$ over this period at a rate of approximately $3.0 \mathrm{~m}^{3} \mathrm{~s}^{-1}$ decade $^{-1}$ (Fig. 4b). Both trends were also significant for the maximum available record period of 1969-2009. The median flood recorded for the comparison period was $11.4 \mathrm{~m}^{3} \mathrm{~s}^{-1}$. Maximum annual discharge values ranged between $6.6 \mathrm{~m}^{3} \mathrm{~s}^{-1}$ and $23.4 \mathrm{~m}^{3} \mathrm{~s}^{-1}$ for the 1985-2009 record period. The majority of floods occurred in mid-to-late summer (Fig. 4c) after the beginning of July (DOY $=190)$ with a median date of the annual flood of July $26($ DOY $=207)$. The occurrences of the annual floods 

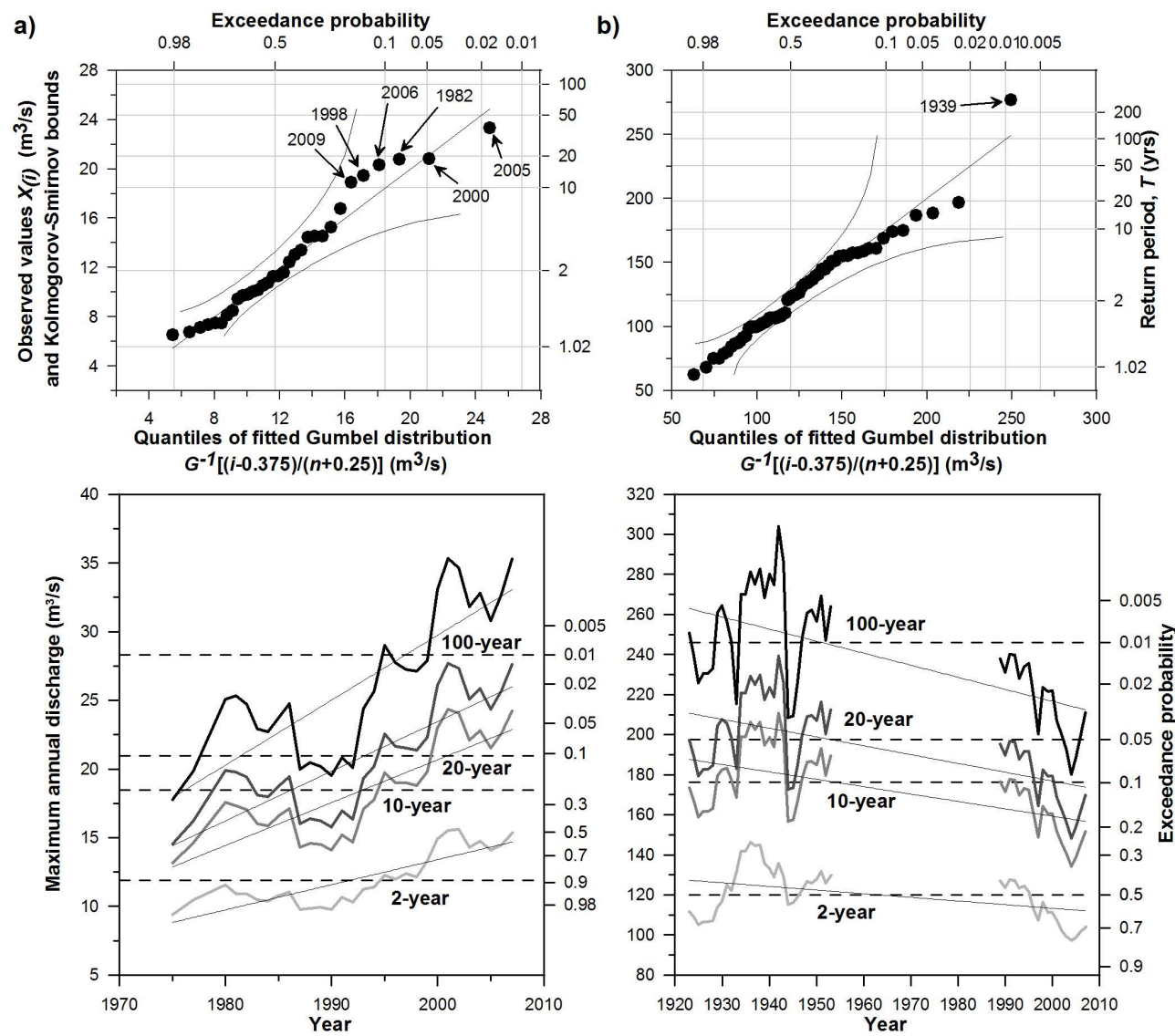

Fig. 5. Top graphs: Plots of annual maximum discharge for (a) Tarfala and (b) Abisko catchments versus quantiles of fitted Gumbel distribution. Bottom graphs: Trends in the 2-yr, 10-yr, 20-yr, and 100-yr return periods (50th, 90th, 95th, and 99th percentile) of the annual maximum flood for the (a) Tarfala and (b) Abisko catchments. Flood records were tested for stationarity by fitting a generalized least squares regression to 10-yr moving window estimated flood quantiles versus calendar year and determining the significance of the regression slope at a significance level of $5 \%$. The solid lines indicate linear trends in the flood records. Dashed lines represent the percentiles estimated from the full record.

showed a decreasing (not significant) trend over the 19852009 period and an increasing albeit not significant trend for the full record period (Fig. 4c).

The flood magnitudes and the mean summer discharge in the Abisko catchment showed a statistically not significant, decreasing trend $(p=0.07)$ and a statistically significant decreasing trend $(p=0.01)$ over the comparison period from 1985-2009, respectively (Figs. 4d and 4e). The rates of decrease in mean summer discharge and flood magnitudes are approximately $-11.7 \mathrm{~m}^{3} \mathrm{~s}^{-1}$ decade $^{-1}$ and $-6.2 \mathrm{~m}^{3} \mathrm{~s}^{-1}$ decade $^{-1}$, respectively for this period. Both the maximum annual discharge events and the mean summer discharge showed insignificant decreasing trends for the full record period (1919-2009). Maximum annual discharge values varied between $75.3 \mathrm{~m}^{3} \mathrm{~s}^{-1}$ and $174.1 \mathrm{~m}^{3} \mathrm{~s}^{-1}$ with a median of $122 \mathrm{~m}^{3} \mathrm{~s}^{-1}$. The occurrences of annual maximum discharge events showed a decreasing, insignificant trend ( $p=$ 0.53 ) over the comparison period at a rate of $1.8 \mathrm{~d} \mathrm{decade}^{-1}$. The median date of the annual flood in Abisko is 16 June
(DOY $=167$ ), with early March to early August as the range of dates for the comparison period (Fig. 4f). However, as indicated in Fig. 4f, in Abisko the majority of flood peaks occur in the first half of the summer snowmelt season before midJuly (DOY =195). Over the long-term period of 1919-2009, the flood timing of Abisko is significantly ( $p=0.01$ ) shifting towards earlier flood occurrences in the spring and summer melt period at a rate of 2 days in $12 \mathrm{yr}$, which is similar to the rate observed for the comparison period.

\subsubsection{Flood frequency analysis}

The Gumbel distribution provided a good fit for both catchments based on a probability plot correlation test (Tarfala: $r=0.98$, Abisko: $r=0.99$ ) (Vogel, 1987). The test for stationarity in the flood quantiles revealed that the Tarfala catchment exhibits a significant increasing trend $(p<0.01)$ in the 2-yr, 10-yr, 20-yr, and 100-yr flood quantile. The lowest probability plot correlation test statistic reached for the 10-yr moving window estimates was $r=0.94$ and $r=0.90$ for the 
Tarfala and Abisko catchments, respectively. Assuming a significance level of $1 \%$, the lower critical value of the PPCC test statistic for $n=10$ values is $r=0.863$ (Vogel, 1987). Thus, for all 10-yr moving window estimates, the Gumbel distribution provided a good fit. The estimated 100-yr flood for Tarfala is $26.8 \mathrm{~m}^{3} \mathrm{~s}^{-1}$ based on the $41-\mathrm{yr}$ record. However, during the past $10 \mathrm{yr}$, the frequency of exceedance of the entire flood distribution moved towards lower exceedance probabilities (Fig. 5a). Five of the seven flood peaks with exceedance probabilities of $20 \%$ or less occurred during the last decade.

The values of the 2-yr, 10-yr, 20-yr, and 100-yr flood quantiles for the Abisko show significant decreasing trends $(p<0.01)$ over the full record period (Fig. 5b, Table 5). The estimated 100-yr flood for Abisko based on the entire 93-yr (1919-2009) record is $246.5 \mathrm{~m}^{3} \mathrm{~s}^{-1}$. The results of the moving window analysis indicate that during the 1919-1955 period, the estimated 100-yr flood showed a greater variability and moved towards lower exceedance probabilities compared to the long-term estimate of $246.5 \mathrm{~m}^{3} \mathrm{~s}^{-1}$ (Fig. 5b). Since 1985, however, the entire flood distribution moved towards higher exceedance probabilities as confirmed by the significant decreasing trend $(p<0.01)$ (Table 5). This means that flood events with a return period of approximately $20-30 \mathrm{yr}$ (values exceeded with a probability of 4-5\%) over the entire record were essentially a $100-$-yr flood (flow values exceeded with a probability of $1 \%$ ) during the past decade.

\subsection{Climatic controls on flood events}

\subsubsection{Temperature and precipitation}

Table 6 summarizes the percentage of years when the annual 1-day maximum and/or annual 3-day maximum for the total precipitation and mean temperature coincided with the observed flood peak for the year. Fifty percent of the flood events that occurred between 1985-2009 in the Tarfala catchment coincided with the annual 1-day maximum precipitation and only $14 \%$ coincided with the annual 1-day maximum temperature (Table 6). It should be noted that for three years, the annual 1-day maximum precipitation coincided with the DOY of the annual 1-day maximum temperature. Similar results were observed when considering the annual 3-day maximum for precipitation and temperature. The majority of the flood events coincided with the median day of occurrence of the maximum annual total precipitation observed over three consecutive days.

For Abisko, the occurrence of floods coincided with the annual 1-day maximum precipitation in $16 \%$ and with the annual 1-day maximum temperature in $16 \%$ of the 25 flood events that occurred in the comparison period of 1985-2009 (Table 6). Thus, floods in Abisko coincided equal times with the maximum annual temperature events and with the maximum annual precipitation events, though neither explained
Table 6. Frequency that the DOY of the annual 1-day maximum precipitation (MAP), the annual 3-day maximum total precipitation (3 day-MP), the 1-day mean air temperature (MAT), and the annual 3-day mean air temperature (3 day-MT) were coincident with the maximum annual flood event. The results are shown for the comparison period of 1985-2009.

\begin{tabular}{cccccc}
\hline & MAP & 3 day-MP & MAT & 3 day-MT & $N$ \\
\hline Tarfala & $50 \%$ & $50 \%$ & $14 \%$ & $9 \%$ & 22 \\
Abisko & $16 \%$ & $16 \%$ & $12 \%$ & $12 \%$ & 25 \\
\hline
\end{tabular}

$N$ - Number of years available for this analysis.

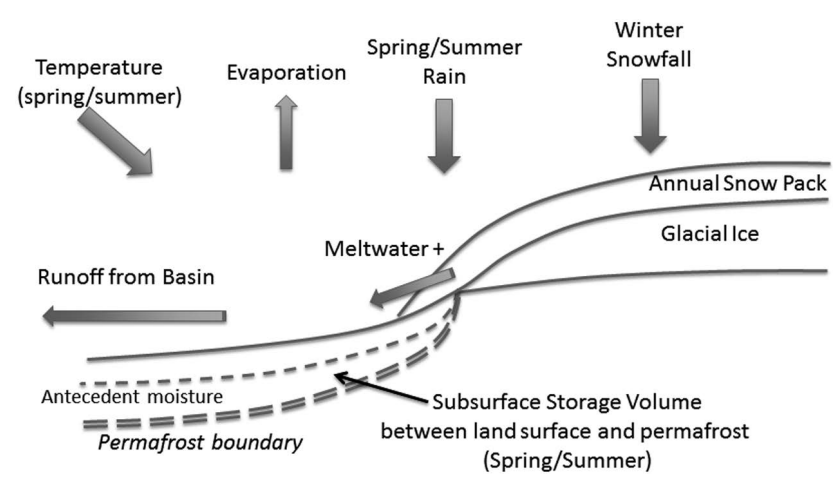

Fig. 6. Dominant hydrometeorologic and hydrologic processes affecting the annual discharge and generation of extreme flood peaks in the Tarfala and Abisko catchments.

the majority of the annual maximum floods. Again, three flood events occurred on the same day as the annual 1day maximum precipitation and temperature. However, this changes when considering the annual 3-day discharge maxima. The flood occurrences coincided with the annual 3-day maximum precipitation in $16 \%$ and with the annual 3-day average maximum temperature in $12 \%$ of the 25 flood events considered. Again, neither explained the majority of the annual maximum floods.

\subsubsection{Climate teleconnections}

The logarithm of the annual maximum discharge for the Tarfala catchment showed a significant positive correlation to the summer average (JJA) and annual average of the AMO index (Table 7). These correlations suggest that (in a linear response sense) one should expect larger floods in years with higher sea surface temperatures over the North Atlantic. This likely predicts higher summer temperatures, precipitation amounts and runoff in these areas (Table 1). The timing of flood occurrences in the Tarfala catchment was not significantly correlated with any of the climate indices considered (Table 7). Mean summer (JJA) discharge in the Tarfala catchment, however, had a significant positive correlation with the annual average of the AMO index and 3-months averages of the winter, spring and summer season (Table 7). In addition, 
Table 7. Correlations between seasonal (3-months averaged) and annual (12-months averaged) anomalies of climate teleconnection patterns and annual maximum flood peaks $\left[\log \left(\right.\right.$ flood)], flood occurrence day (DOY), and mean summer discharge $\left(\bar{Q}_{\text {JJA }}\right)$, for the Tarfala and Abisko catchments and the winter $\left(c_{\mathrm{W}}\right)$, summer $\left(a_{\mathrm{S}}\right)$, net balance $\left(b_{\mathrm{n}}\right)$, equilibrium line altitude (ELA), and accumulation area ratio (AAR) estimates of Storglaciären within the Tarfala catchment. The results are shown for the comparison period of 1985-2009. Correlations that are significant at the $5 \%$ significance level for a 2 -sided test are highlighted in bold.

\begin{tabular}{|c|c|c|c|c|c|c|c|c|c|c|c|c|}
\hline & & \multicolumn{8}{|c|}{ TARFALA } & \multirow{2}{*}{\multicolumn{3}{|c|}{$\begin{array}{l}\text { ABISKO } \\
\text { Discharge }\end{array}$}} \\
\hline & & \multicolumn{3}{|c|}{ Discharge } & \multicolumn{5}{|c|}{ Glacier mass balance } & & & \\
\hline & & $\log ($ flood $)$ & DOY & $\bar{Q}_{\mathrm{JJA}}$ & $c_{\mathrm{W}}$ & $a_{\mathrm{s}}$ & $b_{\mathrm{n}}$ & ELA & AAR & $\log$ (flood) & DOY & $\bar{Q}_{\mathrm{JJA}}$ \\
\hline \multirow[t]{6}{*}{ DJF } & NAO & -0.21 & -0.05 & -0.07 & 0.42 & -0.21 & 0.44 & -0.31 & 0.37 & 0.17 & 0.03 & 0.30 \\
\hline & EA & -0.23 & -0.17 & 0.17 & 0.16 & -0.01 & 0.11 & -0.08 & 0.14 & -0.44 & -0.27 & 0.00 \\
\hline & EA/WR & -0.04 & 0.02 & -0.18 & 0.60 & -0.04 & 0.43 & -0.36 & 0.46 & -0.08 & 0.02 & 0.39 \\
\hline & SCAND & -0.04 & 0.18 & -0.01 & -0.57 & 0.22 & -0.55 & 0.46 & -0.55 & -0.31 & 0.08 & -0.49 \\
\hline & POL & -0.07 & 0.19 & -0.20 & 0.32 & -0.27 & 0.41 & -0.40 & 0.40 & 0.20 & 0.30 & 0.11 \\
\hline & AMO & 0.37 & -0.17 & 0.58 & -0.19 & 0.32 & -0.37 & 0.48 & $-\mathbf{0 . 3 3}$ & 0.00 & 0.16 & -0.32 \\
\hline \multirow{6}{*}{ MAM } & NAO & -0.33 & -0.26 & -0.15 & 0.22 & -0.20 & 0.30 & -0.29 & 0.30 & 0.01 & -0.10 & 0.24 \\
\hline & EA & 0.22 & 0.05 & 0.21 & -0.15 & 0.16 & -0.22 & 0.19 & -0.14 & -0.24 & -0.38 & -0.23 \\
\hline & EA/WR & 0.25 & -0.11 & 0.18 & -0.09 & -0.21 & 0.09 & -0.09 & 0.09 & -0.04 & -0.32 & 0.05 \\
\hline & SCAND & -0.37 & -0.07 & -0.21 & -0.19 & 0.12 & -0.21 & 0.15 & -0.22 & -0.17 & -0.05 & -0.09 \\
\hline & POL & -0.09 & 0.13 & -0.24 & 0.17 & -0.12 & 0.20 & -0.23 & 0.16 & -0.14 & -0.24 & 0.22 \\
\hline & AMO & 0.39 & 0.16 & 0.50 & -0.16 & 0.33 & -0.35 & 0.45 & -0.35 & 0.08 & 0.13 & -0.19 \\
\hline \multirow[t]{6}{*}{ JJA } & NAO & -0.15 & 0.05 & -0.25 & 0.15 & 0.26 & -0.09 & -0.15 & 0.07 & 0.01 & -0.24 & 0.08 \\
\hline & $\mathrm{EA}$ & 0.16 & -0.18 & 0.34 & -0.39 & 0.21 & -0.42 & 0.44 & -0.38 & -0.34 & -0.21 & -0.38 \\
\hline & EA/WR & -0.23 & -0.17 & -0.29 & -0.16 & -0.10 & -0.03 & -0.02 & -0.11 & -0.23 & -0.23 & -0.20 \\
\hline & SCAND & -0.38 & 0.12 & -0.14 & 0.14 & 0.28 & -0.12 & 0.10 & -0.06 & -0.04 & -0.18 & -0.08 \\
\hline & POL & -0.07 & -0.29 & -0.18 & 0.16 & -0.12 & 0.19 & -0.26 & 0.27 & 0.13 & -0.19 & 0.04 \\
\hline & AMO & 0.54 & 0.15 & 0.59 & -0.12 & 0.13 & -0.18 & 0.30 & -0.19 & 0.17 & 0.09 & -0.22 \\
\hline \multirow[t]{6}{*}{ Annual } & NAO & -0.02 & 0.26 & -0.05 & 0.51 & -0.11 & 0.43 & 0.40 & -0.24 & 0.15 & 0.17 & 0.42 \\
\hline & EA & 0.22 & -0.09 & 0.41 & -0.04 & 0.04 & -0.06 & -0.44 & 0.36 & -0.18 & -0.33 & -0.19 \\
\hline & EA/WR & -0.30 & -0.09 & -0.20 & 0.25 & 0.05 & 0.13 & 0.16 & -0.09 & -0.08 & 0.07 & 0.27 \\
\hline & SCAND & -0.29 & -0.04 & -0.18 & -0.18 & 0.12 & -0.21 & -0.28 & 0.20 & -0.17 & 0.04 & -0.18 \\
\hline & POL & -0.17 & 0.06 & 0.02 & 0.25 & -0.11 & 0.25 & 0.26 & -0.33 & 0.28 & 0.18 & 0.35 \\
\hline & AMO & 0.44 & -0.04 & 0.66 & -0.26 & 0.23 & -0.35 & 0.45 & -0.25 & -0.09 & 0.06 & -0.33 \\
\hline
\end{tabular}

Table 8. Summary of trends observed in the Swedish Tarfala and Abisko catchments. Streamflow dynamics and flood events in northern landscapes are typically driven by either snowmelt (thermally driven) in the spring or the occurrence of precipitation events during the late summer and autumn.

\begin{tabular}{lllllllll}
\hline Basin & $\begin{array}{l}\text { Basin } \\
\text { area }\end{array}$ & $\begin{array}{l}\text { Glacier } \\
\text { cover }\end{array}$ & $\begin{array}{l}\text { Mean annual } \\
\text { air temperature }\end{array}$ & $\begin{array}{l}\text { Annual } \\
\text { precipitation }\end{array}$ & $\begin{array}{l}\text { Flood } \\
\text { magnitude }\end{array}$ & $\begin{array}{l}\text { Flood } \\
\text { timing }\end{array}$ & $\begin{array}{l}\bar{Q}_{\text {JJA }} \\
\text { Hydrologic } \\
\text { effect }\end{array}$ \\
\hline Tarfala & $21.7 \mathrm{~km}^{2}$ & $30 \%$ & Increase & n.s. & Increase & n.s. & Increase & Amplified* \\
Abisko & $566 \mathrm{~km}^{2}$ & $1 \%$ & Increase & Increase ${ }^{1}$, n.s. $^{2}$ & -n.s. & Decrease $^{1}$, -n.s. $^{2}$ & Decrease $^{\text {Dampened }}$ \\
\hline
\end{tabular}

1 - for period $1913-2009 ;^{2}$ - for period $1985-2009 ;$ n.s. means the process did not exhibit a statistically significant trend at the $5 \%$ level, although the trend was negative (decrease) for the Abisko catchment $(-) ;{ }^{*}$ Increasing trend in the flood magnitudes and summer discharge; ${ }^{* *}$ Decrease in the mean summer discharge and flood magnitudes and trend towards earlier flood occurrences.

the mean summer (JJA) discharge in the Tarfala catchment had a significant positive correlation with the annual average of the EA index (Table 7). The positive phase of the EA index is associated with negative height anomalies east of Newfoundland that lead to above normal temperatures in $\mathrm{Eu}-$ ropean Russia but above normal precipitation across northern
Fennoscandia (Table 1). This likely predicts greater summer precipitation and runoff amounts in the Tarfala catchment.

For the Abisko catchment, the logarithms of the maximum annual flood events were negatively correlated with the winter (DJF) EA index (Table 7). The negative phase of the EA index is associated with an intensification of the meridional circulation that leads to a negative temperature anomaly 
Table 9. Correlations between the annual winter $\left(c_{\mathrm{W}}\right)$, summer $\left(a_{\mathrm{S}}\right)$, net balance $\left(b_{\mathrm{n}}\right)$, equilibrium line altitude (ELA), and accumulation area ratio (AAR) estimates of Storglaciären and the annual maximum flood peaks ( $\log ($ flood)), flood occurrences (DOY), and mean summer discharge $\left(\bar{Q}_{\text {JJA }}\right)$ for the Tarfala catchment for the comparison period 1985-2009. Correlations that are significant at the $5 \%$ significance level for a 2 -sided test are indicated in bold.

\begin{tabular}{lrrrrrrrr}
\hline & $c_{\mathrm{W}}$ & $a_{\mathrm{S}}$ & $b_{\mathrm{n}}$ & ELA & AAR & $\log$ (flood) & DOY & $\bar{Q}_{\text {JJA }}$ \\
\hline$c_{\mathrm{W}}$ & 1 & -0.39 & $\mathbf{0 . 8 3}$ & $\mathbf{- 0 . 7 6}$ & $\mathbf{0 . 8 2}$ & -0.24 & 0.09 & -0.24 \\
$a_{\mathrm{S}}$ & & 1 & $-\mathbf{0 . 8 4}$ & $\mathbf{0 . 7 2}$ & $-\mathbf{0 . 6 7}$ & 0.23 & 0.22 & 0.23 \\
$b_{\mathrm{n}}$ & & & 1 & $-\mathbf{0 . 8 9}$ & $\mathbf{0 . 8 9}$ & -0.28 & -0.08 & -0.28 \\
ELA & & & & 1 & $-\mathbf{0 . 9 5}$ & 0.34 & 0.06 & $\mathbf{0 . 4 0}$ \\
AAR & & & & & 1 & -0.28 & -0.01 & -0.28 \\
log (flood) & & & & & 1 & 0.26 & $\mathbf{0 . 6 7}$ \\
DOY & & & & & & & 1 & 0.16 \\
$\bar{Q}_{\text {JJA }}$ & & & & & & & & 1 \\
\hline
\end{tabular}

or below average temperatures and above normal precipitation over northern Europe (Table 1). Thus, in the Abisko catchment one should expect larger floods in summers following winters with the EA index in the negative phase. Predominance of the EA index in the negative phase during the winter season likely predicts greater precipitation amounts and thus greater snow accumulation in the Abisko catchment. The timing of flood occurrences in the Abisko catchment showed a significant negative correlation with the spring (MAM) average of the EA index (Table 7). The mean summer discharge in the Abisko catchment showed a significant negative correlation with the winter (DJF) SCAND index, the summer EA index and significant positive correlations to the annual average of the NAO and POL index (Table 7). The negative phase of both the EA and the SCAND index cause negative height pressure anomalies over northern $\mathrm{Eu}-$ rope and Fennoscandia that lead to lower temperatures and above normal precipitation (Table 1). Similarly, the positive phase of both the NAO and the POL index are characterized by above normal precipitation and above normal winter and spring temperatures in Fennoscandia, which likely signify greater precipitation and runoff amounts in Abisko during the summer season.

\section{Discussion}

\subsection{Regional precipitation and temperature trends}

Figure 6 provides a visual summary of the hydrometeorologic and hydrologic processes in these two basins. Characteristics of the two catchments and the results of critical statistical trend tests are summarized in Table 8. The data show that there is a clear increase in the annual mean temperature in both catchments over the respective common and long-term time periods associated largely to statistically significant increases of spring temperatures in the Abisko catchment and of winter temperatures in the Tarfala catchment (Figs. 2 and 3, Tables 2, 3 and 4). With the exception of the winter period, trends in the annual and sea- sonal minimum temperature were not statistically significant in either catchment. The slope of the mean annual temperature rise in the Abisko catchment over the 1913-2009 period agrees with evidence that Arctic air temperature has been rising at an average rate of 0.09 decade $^{-1}$ since 1875 (Table 3) (Polyakov et al., 2003; Trenberth et al., 2007). The long-term (1913-2009) seasonal temperature trends observed at the Abisko Scientific Research Station are in general agreement with the results of Jones et al. (1999), Serreze et al. (2000) and Polyakov et al. (2003) who observed the smallest warming trend in summer $(\mathrm{JJA})\left(0.05^{\circ} \mathrm{C}\right.$ decade $^{-1}$; Abisko: $0.03^{\circ} \mathrm{Cdecade}^{-1}$ ) and the largest warming trend during the winter and spring (DJF, MAM) $\left(0.13\right.$ and $0.12^{\circ} \mathrm{C}$ decade $^{-1}$, respectively; Abisko: 0.08 and $0.15^{\circ} \mathrm{C} \mathrm{decade}^{-1}$, respectively) within the $55-85^{\circ} \mathrm{N}$ zonal band. The rise in mean annual temperature that was recorded in both catchments since $1985\left(0.67\right.$ and $0.96^{\circ} \mathrm{C}$ decade $^{-1}$ for the Abisko and Tarfala catchment, respectively) is consistent with mean annual temperature trends reported for Scandinavia and the Baltic Sea area by Callghan et al. (2010) and Lehman et al. (2011). In addition, there is a diurnal asymmetry in the warming in the Tarfala catchment comprised of a rise in minimum temperature at a rate three times the rate of the increase in the maximum temperature. This trend is consistent with observations by Karl et al. (1993) and Rusticucci and Barrucand (2004) of large parts of the northern and southern hemisphere landmass. In contrast there was an increase in minimum temperature (for all seasons) and a decrease in the maximum summer temperature in the Abisko catchment (Tables 2, 3 and 4).

Precipitation is another critical variable in flood generation. The Tarfala catchment did not show significant increasing or decreasing trends in the total and maximum summer precipitation. For the Abisko catchment a significant decreasing trend in the winter precipitation was found for the comparison period 1985-2009. In addition, the long-term record (1913-2009) showed a significant increase in annual precipitation. Although the frequency of precipitation events remained unchanged in both catchments over a long-term 
period (Fig. 3), the variability and magnitude of extreme precipitation events were increasing. These trends are consistent with findings reported by Busuioc et al. (2001), Callaghan et al. (2010) and Birsan et al. (2005), who hypothesize changes in the large-scale circulation patterns, increased moisture transport to arctic regions and the lack of adequate rain gauge coverage to capture the large spatial variability of precipitation as potential reasons for the inconsistent trends.

\subsection{Shifting hydrology and hydrological extremes}

Although both catchments demonstrated similar precipitation and temperature trends over the common time periods, we found contrasting trends in the mean summer discharge, as well as the flood magnitude and flood timing between the Abisko and Tarfala catchments. The Tarfala catchment showed a statistically significant increase in the mean summer discharge and the magnitude of flood peaks, and an insignificant decrease in the flood occurrences over the comparison period of 1985-2009 (Fig. 3). Flood peaks showed a significant correlation to the mean summer discharge. This is suggesting that generally wetter conditions in the catchment either due to above-normal precipitation amounts or due to increased glacier melt could increase the disposition of high-magnitude flood events. Wetter conditions were found in years with above-normal sea surface temperatures across the North Atlantic (indicated by a significant correlation to the AMO index (Table 7)) and a more negative glacier net balance. In addition, mean summer discharge in the Tarfala catchment showed a significant correlation $(r=0.4)$ with the ELA of Storglaciären (Table 8). This is suggesting that runoff generation is increased in years with a higher ELA, which corresponds to a more negative $b_{\mathrm{n}}$ and a lower AAR (Table 8). Together these relationships suggest the following mechanistic changes in the Tarfala catchment. The observed decreasing trend in Storglaciären's net balance since 1985 is associated with a decreasing trend in the glaciers AAR. As indicated by the significant correlation between ELA and the mean summer discharge (Table 8), this could potentially increase melt water production due to earlier and more extensive disappearance of high-albedo glacial snow and firn. The reduction in firn-covered surface area and firn pack thickness, and greater exposure of low-albedo bare ice is likely reducing the water retention capacity, allowing greater melt, and potentially increasing the volume and peak flows of water over the glacier surface (Hock et al., 2005). Similar linkages between air temperature, variations in the $c_{\mathrm{W}}, a_{\mathrm{s}}$, and streamflow trends have been observed by Fleming and Clarke (2003), Huss et al. (2008), and Pellicciotti et al. (2010) in catchments with considerable $(>10 \%)$ glacier cover, which are supporting our results.

Trends in air temperature alone cannot explain the observed trends in the magnitude and timing of flood peaks in the Tarfala catchment, because $50 \%$ of the flood events coincided with the annual 1-day maximum precipitation and only
$14 \%$ coincided with the annual 1-day maximum temperature (Table 6). The temperature-induced decrease in the net balance of Storglaciären and the associated increased melt water contribution could represent an important precursor for an increased flood generation in the Tarfala catchment by increasing streamflow and providing fast runoff pathways when glacial snow/firn cover is low. However, the high coincidence between flood events and the maximum annual precipitation suggests that large precipitation events, especially when occurring late in the summer season when the catchment snow cover is removed, could be the primary reason for the observed amplification of flood extremes. This is also supported by the observed increase in extreme precipitation during the last decade. In addition, we found that a low AAR and negative glacier net balance in the Tarfala catchment occurred predominantly in years with the seasonal summer EA index in the positive phase, which is characterized by above-average precipitation over Scandinavia (Table 7). Together, these results indicate the increasing importance of rainfall for flood generation. These findings are consistent with studies from Kane et al. (2003) and Cunderlik and Ouarda (2009). Kane et al. (2003) showed in the Upper Kuparuk River, Alaska that rainfall-generated runoff events produce flood magnitudes that can exceed by a factor of three of those generated by snowmelt. They concluded that the likelihood of major rainfall-generated floods is especially prevalent in catchments with limited soil storage and steep topography. However, catchment size and the orientation of the catchment to predominant weather patterns are also important factors (Kane et al., 2003). Similarly, Cunderlik and Ouarda (2009) reported that the importance of rainfall floods has been increasing across continental arctic and sub-arctic Canada during the past three decades, while magnitudes of snowmelt floods showed significant negative trends.

In contrast to the hydrologic amplification observed in the Tarfala catchment, the Abisko catchment showed significant decreasing trends in the mean summer discharge and in the magnitude of flood peaks (significant at $10 \%$ level) suggesting changes in the catchment hydrology that diminish flood intensities. In addition, the Abisko catchment showed a negative trend in the timing of flood peaks, which is significant for the long-term record period, implying that the occurrence of floods is shifting toward the earlier part of the year. The mean summer discharge and flood magnitudes in the Abisko catchment showed significant correlations to the annual NAO index and the EA index of the previous winter season (Table 7). Because both the NAO index and the EA index are reliable indicators of large-scale moisture and energy flow into northern Europe, it is possible that winter precipitation and the build-up of the winter snow pack subsequently affect streamflow dynamics in the spring and summer melt season. These results agree with results of previous studies from non-glacierized, permafrost dominated catchments in Fennoscandia (Korhonen and Kuusisto, 2010; Wilson et al., 2010), Sub-Arctic Canada (Carey and Woo, 2001; 
Dery and Wood, 2005; Abdul-Aziz and Burn, 2006; Cunderlik and Ouarda, 2009; Khaliq et al., 2009, Burn et al., 2010), and Alaska (Woo and Thorne, 2008; Brabets and Walvoord, 2009; Hodgkins, 2009) which discuss a similar range of explanations for the observed trends. Burn et al. (2010) hypothesized that the decreasing trend in flood magnitudes and occurrences is the results of increased winter and spring temperatures that lead to greater losses of the snowpack before the onset of spring melt. Meteorological records from the Abisko catchment indicate a significant increase in the winter and spring air temperature and a negative, albeit insignificant $(p=0.35)$, trend in winter precipitation, which could result in similar reductions in the spring snow pack and an extension of the snow-free summer melt period (Table 4).

On the other hand, higher temperatures can result in increased permafrost thawing; that can lead to increased retention capacity of unfrozen ground and increased subsurface flow through the active layer that could potentially have a dampening effect on peak flows (Lyon et al., 2009, 2010). Indeed, several studies across sub-arctic Sweden have documented accelerated permafrost thawing. Malmer et al. (2005) reported that areas of ponds have increased while areas with dry palsa tops have decreased. For the Abisko catchment, Åkerman and Johansson (2008) documented increases in active layer thickness in nine lowland mires with discontinuous permafrost between 1978 and 2006, and estimated an average permafrost thawing rate of $0.7-1.3 \mathrm{~cm} \mathrm{yr}^{-1}$ based on those data. This progressive increase in active layer thickness is likely to cause increased water flow via subsurface flow pathways as indicated by the negative trend in mean summer discharge in the Abisko catchment. Similar indicators of a progressive increase in catchment storage have been documented by means of a greater annual discharge (Lindström and Bergström, 2004), increased total organic carbon (TOC) export rates to lakes (Kokfelt et al., 2009), and increased dissolved inorganic carbon (DIC) exports to streams (Lyon et al., 2010).

Altogether our results suggest that the effect of climate warming on the arctic and sub-arctic hydrologic system can fundamentally change the hydrologic responses of those systems (Fig. 6 and Table 9). Our observations indicate that subarctic mountain catchments can experience an amplified response to climate forcing relative to that found for lower altitudes. In the glacierized Tarfala catchment, trends in hydrological extremes (floods) indicate that this catchment is becoming more efficient in transmitting water to its outlet. This can be attributed in large parts to the negative trends in the net balance and associated reduction in snow cover and firn volume and, thus, water retention capacity (Hock et al., 2005). Conversely, in the Abisko catchment, research has shown that the mean soil depth and soil water storage capacity is increasing with the melting of permafrost; as a result the annual maximum discharge events and streamflow exhibit a generally decreasing trend likely due to the dampening effect of increased sub-surface catchment stor- age. In addition, the decreases in mean summer discharge and flood magnitudes in the Abisko catchment are likely the result of earlier snowmelt, as indicated by the decreasing trend in flood occurrences associate with warming climate and thawing permafrost. We suggest that the increase in mean summer discharge in the glacierized Tarfala catchment is due to higher temperatures promoting enhanced melt water production due to earlier and more extensive disappearance of high-albedo glacial snow, earlier melt of the catchment snow cover, and increased summer precipitation (positive but insignificant trend), which could promote wetter conditions and increased connectivity of hydrologic flow pathways within the catchment. On the other hand, the increase in flood magnitudes of Tarfala is likely due to the increase in extreme precipitation events in conjunction with catchment properties that promote fast runoff such as low glacial snow and firn cover, high antecedent wetness in years with above-normal precipitation and increased mean streamflow due to increased glacier melt. However, does glacier presence matter for the observed trends in flooding extremes? Based on our results we conclude that for flood extremes it appears that glacier presence and particularly the amount of glacier melt in response to climatic forcing play a key role in runoff production in mountain catchments. However, the potential role of changes in the snow cover characteristics should to be examined in more depth. A reduction in the seasonal snow cover in non-glacierized catchments would potentially lead to a decrease in streamflow from these catchments due to the reduced precipitation input, while the same reduction in a glacierized catchment would potentially leave the glacier ice exposed for a longer time, thus resulting in a short term increase in streamflow until depletion of the glacier mass reaches the critical stage after which streamflow will decrease (Jansson et al., 2003).

\section{Conclusions}

Despite the similarity in precipitation and temperature trends, the $30 \%$ and $1 \%$ glacierized Tarfala and Abisko catchments in sub-arctic northern Sweden exhibited fundamentally different trends in the mean summer discharge, and in the flood magnitude and timing. The glacierized Tarfala catchment showed a statistically significant increase in the mean summer discharge and the magnitude of flood peaks, and progressively earlier flood occurrences (not significant); the non-glacierized Abisko catchment showed a significant decrease in the mean summer discharge and in the flood magnitudes at the $10 \%$ level and a insignificant trend towards earlier flood occurrences during the past three decades. Correlation analyses of hydrologic trends in the Tarfala catchment with glacier mass balance data and climate pattern indices show statistically significant relationships for both the flood peaks and the mean summer discharge with the winter balance of Storglaciären and the Atlantic multidecadal 
oscillation. These relationships suggest that climatic forcing (e.g. reduction in snow cover) on the glacier net balance in the Tarfala catchment affect the streamflow dynamics in the summer melt season. The increase in flood magnitudes, however, is clearly correlated to an increase in extreme precipitation events in conjunction with catchment properties that promote fast runoff, such as low glacial snow and firn cover, high antecedent wetness in years with above-normal precipitation and increased mean streamflow due to increased glacier melt. Conversely, the decreasing trends observed in the non-glacierized Abisko catchment in combination with the precipitation and temperature trends point towards a reduction of the winter snow pack due to higher temperatures and an increasing sub-surface storage capacity or catchment storage due to progressively thawing permafrost. Together these results show that similar climate forcing can cause fundamentally different responses of hydrologic systems in the Arctic and Sub-Arctic.

Acknowledgements. We would like to thank the Abisko Scientific Research Station for provision of the meteorological and hydrometric data. In addition we would like to thank the Swedish Society of Anthropology and Geography for financial support and the three reviewers of this manuscript for their helpful comments.

Edited by: M. Weiler

\section{References}

Abdul-Aziz, O. I. and Burn, D. H.: Trends and variability in the hydrological regime of the Mackenzie River basin, J. Hydrol., 319, 282-294, 2006.

Åkerman, H. J. and Johansson, M.: Thawing permafrost and thicker active layers in sub-arctic Sweden, Permafrost and Periglacial Proc., 19, 279-292, 2008.

Alexandersson, H., Karlström, C., and Larsson-McCann, S.: Temperature and precipitation in Sweden 1961-90 reference normal, SMHI Meteorol. Klim. 81, Uppsala, Sweden, 1991.

Arguez, A., O'Brien, J. J., and Smith, S. R.: Air temperature impacts over Eastern North America and Europe associated with low-frequency North Atlantic SST variability, Int. J. Climatol., 29, 1-10, 2009.

Barnston, A. G. and Livezey, R. E.: Classification, seasonality and persistence of low-frequency atmospheric circulation patterns, Mon. Weather Rev., 115, 1083-1126, 1987.

Birsan, M.-V., Molnar, P., Burlando, P., and Pfaundler, M.: Streamflow trends in Switzerland, J. Hydrol. 314, 312-329, 2005.

Box, J., Yang, L., Rogers, J., Bromwish, D., Bai, L-S., Steffen, K., Stroeve, J., and Wang, S.-H.: Extreme precipitation events over Greenland: consequences to ice sheet mass balance, Proc. 8th International Conference on Polar Meteorology and Oceanography, American Meteorological Society, San Diego, 9-13 January, American Meteorology Society, San Diego, CA, USA, CD-ROM 5.2., 2005.

Brabets, T. P. and Walvoord, M. A.: Trends in streamflow in the Yukon River Basin from 1944 to 2005 and the influence of the Pacific Decadal Oscillation, J. Hydrol., 371, 108-119, 2009.
Braun, L. N., Weber, M., and Schulz, M.: Consequences of climate change for runoff from Alpine regions, Ann. Glaciol., 31, 19-25, 2000.

Burn, D. H., Sharif, M., and Zhang, K.: Detection of trends in hydrological extremes for Canadian watersheds, Hydrol. Process., 24, 1781-1790, 2010.

Busuioc, A., Chen, D. L., and Hellstrom, C.: Temporal and spatial variability of precipitation in Sweden and its link with the largescale atmospheric circulation, Tellus A, 53, 348-367, 2001.

Callaghan, T. V., Bergholm, F., Christensen, T. R., Jonasson, C., Kokfelt, U., and Johansson, M.: A new climate era in the subArctic: Accelerating climate changes and multiple impacts, Geophys. Res. Lett., 37, L14705, doi:10.1029/2009GL042064, 2010.

Carey, S. K. and Woo, M. K.: Slope runoff processes and flow generation in a subarctic, subalpine catchment, J. Hydrol., 253, 110129, 2001.

Casassa G., Lopez P., Pouyaud B., and Escobar F.: Detection of changes in glacial run-off in alpine basins: examples from North America, the Alps, central Asia and the Andes, Hydrol. Process., 23, 31-41, 2009.

Cayan, D. R., Redmond, K. T., and Riddle, L. G.: ENSO and hydrologic extremes in the western United States, J. Climate, 12, 2881-2893, 1999.

Chatfield, C.: Analysis of Time Series: An Introduction, Fourth Edition. London: Chapman and Hall, 1989.

Climate Diagnostics Bulletin. US Dept. of Commerce: Center of NOAA-CIRES, 2003, http://www.cdc.noaa.gov, 2001.

Cogley, J. G., Hock, R., Rasmussen, L. A., Arendt, A. A., Bauder, A., Braithwaite, R. J., Jansson, P., Kaser, G., Möller, M., Nicholson, L., and Zemp, M.: Glossary of Glacier Mass Balance and Related Terms. IHP-VII Technical Documents in Hydrology No. 86, IACS Contribution No. 2, UNESCO-IHP, Paris, 2011.

Cunderlik, J. M. and Ouarda, T.: Trends in the timing and magnitude of floods in Canada, J. Hydrol., 375, 471-480, 2009.

Dery, S. J. and Wood, E. F.: Decreasing river discharge in northern Canada, Geophys. Res. Lett., 32, L10401, doi:10.1029/2005GL022845, 2005.

Dery, S. J., Stieglitz, M., McKenna, E. C., and Wood, E. F.:Characteristics and Trends of River Discharge into Hudson, James, and Ungava Bays, 1964-2000, J. Climate, 18, 25402557, 2005.

Douglas, E. M., Vogel, R. M., and Kroll, C. N.: Trends in floods and low flows in the United States: impact of spatial correlation, J. Hydrol., 240, 90-105, 2000.

Durbin, J. and Watson, G. S.: Testing for serial correlation in Least squares regression, I, Biometrika 37, 409-428, 1950.

Enfield, D. B., Mestas-Nunez, A. M., and Trimble, P. J.: The Atlantic Multidecadal Oscillation and its relationship to precipitation and river flows in the continental U.S., Geophys. Res. Lett., 28, 2077-2080, 2001.

Fleming, S. W. and Clarke, G. K. C.: Glacial control of water resources and related environmental responses to climatic warming: empirical analysis using historical streamflow data from Northwestern Canada, Can. Water Res. J., 28, 69-86, 2003.

Fleming, S. W., Moore, R. D., and Clarke, G. K. C.: Glaciermediated streamflow teleconnections to the Arctic Oscillation, Int. J. Climatol., 26, 619-636, 2006.

Fountain, A. G. and Tangborn, W. V.: The effect of glaciers on streamflow variations, Water Resour. Res., 21, 579-586, 1985. 
Fox, J. and Hartnagel. T. F.: Changing Social Roles and Female Crime in Canada: A Time Series Analysis. Can. Rev. Sociol. Anthr., 16, 96-104, 1979.

Groisman, P. Y., Knight, R. W., Easterling, D. R., Karl, T. R., Hegerl, G. C., and Razuvaev, V. N.: Trends in intense precipitation in the climate record, J. Clim. 18, 1326-1350, 2005.

Gumbel, E. J.: Statistics of extremes, New York, Columbia University Press, 375 pp., 1958.

Helsel, D. R., and Hirsch, R. M.: Statistical Methods in Water Resources, Elsevier, New York, USA, 522 pp., 1992.

Hock, R., Jansson, P., and Braun, L.: Modelling the response of mountain glacier discharge to climate warming, In: Huber, U. M., Reasoner, M. A., and Bugmann, H. (eds): Global Change and Mountain Regions - A State of Knowledge Overview. Springer, Dordrecht, The Netherlands, 243-252, 2005.

Hodgkins, G. A.: Streamflow changes in Alaska between the cool phase (1947-1976) and the warm phase (1977-2006) of the Pacific Decadal Oscillation: The influence of glaciers, Water Resour. Res. 45, doi: 10.1029/2008WR007575, 2009.

Holmlund, P., Jansson, P., and Pettersson, R.: A re-analysis of the 58 year mass-balance record of Storglaciären, Sweden, Ann. Glaciol., 42, 389-394, 2005.

Huss, M., Farinotti, D., Bauder, A., and Funk, M.: Modelling runoff from highly glacierized alpine drainage basins in a changing climate, Hydrol. Process., 22, 3888-3902, 2008.

Jain, S. and Lall, U.: Floods in a changing climate: Does the past represent the future?, Water Resour. Res., 37, 3193-3205, 2001.

Jansen, E., Overpeck, J., Briffa, K. R., Duplessy, J.-C., Joos, F., Masson-Delmotte, V., Olago, D., Otto-Bliesner, B., Peltier, W. R., Rahmstorf, S., Ramesh, R., Raynaud, D., Rind, D., Solomina, O., Villalba, R., and Zhang, D.: Palaeoclimate, in Climate Change 2007: The Physical Science Basis, Contribution of Working Group I to the Fourth Assessment Report of the Intergovernmental Panel on Climate Change, edited by: Solomon, S., Qin, D., Manning, M., Chen, Z., Marquis, M., Averyt, K. B., Tignor, M., and Mille, H. L., 433-497, Cambridge Univ. Press, Cambridge, UK, 2007.

Jansson, P. and Pettersson, R.: Spatial and Temporal Characteristics of a Long Mass Balance Record, Storglaciären, Sweden, Arct. Antarct. Alp. Res., 39, 432-437, 2007.

Jansson, P., Hock, R., and Schneider, T.: The concept of glacier storage - a review, J. Hydrol., 282, 115-129, doi:10.1016/S00221694(03)00258-0, 2003.

Jenkinson, A. F.: Statistics of extremes. In: Estimation of Maximum Floods, World Meteorol. Organ. Rep. 98, chap. 5, 193-227, Geneva, 1969.

Jones, P. D., New, M., Parker, D. E., Martin, S., and Rigor, I. G.: Surface air temperature and its changes over the past 150 years, Rev. Geophys., 37, 173-199, 1999.

Josefsson, M.: Ground Temperature Variations in a Subarctic Mountain Valley, Abisko, Northern Sweden, Geogr. Ann. A, 72, 179-190, 1990.

Kane, D. L., McNamara, J. P., Yang, D., Olsson, P. Q., and Gieck, R. E.: An extreme rainfall/runoff event in Arctic Alaska, J. Hydrometeorol., 4, 1220-1228, 2003.

Karl, T. R., Jones, P. D., Knight, R. W., Kukla, G., Plummer, N., Razuvayev V., Gallo, K. P., Lindseay, J., Charlson, R. J., and Peterson, T. C.: A new perspective on recent global warming Asymmetric trends of daily maximum and minimum tempera- ture, Bull. Am. Meteorol. Soc., 74(6), 1007-1023, 1993.

Kendall, M. G.: Rank Correlation Measures, Charles Griffin, London, UK, 202 pp., 1975.

Khaliq, M. N., Ouarda, T., Ondo, J. C., Gachon, P., and Bobee, B.: Frequency analysis of a sequence of dependent and/or nonstationary hydro-meteorological observations: A review, J. Hydrol., 329, 534-552, 2006.

Khaliq, M. N., Ouarda, T., and Gachon, P.: Identification of temporal trends in annual and seasonal low flows occurring in Canadian rivers: The effect of short- and long-term persistence, J. Hydrol., 369, 183-197, 2009.

Knudsen, N. T. and Hasholt, B.: Mass balance observations at Mittivakkat Glacier, Southeast Greenland, 1995-2002. Proceedings of the 14th Northern Research Basins Symposium and Workshop, Kangerlussuq/Sdr. Strømfjord, Greenland, 25-29 August, University of Copenhagen, Copenhagen, 77-84, 2003.

Koblet, T., Gärtner-Roer, I., Zemp, M., Jansson, P., Thee, P., Haeberli, W., and Holmlund, P.: Reanalysis of multi-temporal aerial images of Storglaciären, Sweden (1959-99) - Part 1: Determination of length, area, and volume changes, The Cryosphere, 4, 333-343, doi:10.5194/tc-4-333-2010, 2010.

Kokfelt, U., Rosen, P., Schoning, K., Christensen, T., Förster, J., Karlsson, J., Reuss, N., Rundgren, M., Callaghan, T., Jonasson, C., Hammarlund, D.: Ecosystem responses to increased precipitation and permafrost decay in subarctic Sweden inferred from peat and lake sediments, Global Change Biol., 15, 1652-1663, 2009.

Korhonen, J. and Kuusisto, E.: Long-term changes in the discharge regime in Finland, Hydrol. Res., 41, 253-268, 2010.

Lehmann, A., Getzlaff, K., and Harlass, J.: Detailed assessment of climate variability in the Baltic Sea area for the period 1958 to 2009, Clim. Res., 46, 185-196, 2011.

Lindström, G. and Bergström, S.: Runoff trends in Sweden, 18072002, Hydrol. Sci. J., 49, 69-83, 2004.

Lyon, S. W., Destouni, G., Giesler, R., Humborg, C., Mörth, M., Seibert, J., Karlsson, J., and Troch, P. A.: Estimation of permafrost thawing rates in a sub-arctic catchment using recession flow analysis, Hydrol. Earth Syst. Sci., 13, 595-604, doi:10.5194/hess-13-595-2009, 2009.

Lyon, S. W., Mörth, M., Humborg, C., Giesler, R., and Destouni, G.: The relationship between subsurface hydrology and dissolved carbon fluxes for a sub-arctic catchment, Hydrol. Earth Syst. Sci., 14, 941-950, doi:10.5194/hess-14-941-2010, 2010.

Malmer, N., Johansson, T., Olsrud, M., and Christensen, T. R.: Vegetation, climatic changes and net carbon sequestration in a northScandinavian subarctic mire over 30 years, Global Change Biol., 11, 1895-1909, 2005.

Moberg, A., Sonechkin, D. M. , Holmgren, K., Datsenko, N. M., and Karlén, W.: Highly variable Northern Hemisphere temperatures reconstructed from low- and high-resolution proxy data, Nature, 433, 613-617, doi:10.1038/nature03265, 2005.

Moore, R. and Demuth, M.: Mass balance and streamflow variability at Place Glacier, Canada, in relation to recent climate fluctuations, Hydrol. Process., 15, 3473-3486, 2001.

Nesterov, E. S.: East Atlantic oscillation of the atmospheric circulation, Russ. Meteorol. Hydrol., 34, 794-800, 2009.

Panagiotopoulos, F., Shahgedanova, M., and Stephenson, D. B.: A review of Northern Hemisphere winter-time teleconnection patterns, J. Phys. IV, 12, 27-47, 2002. 
Pellicciotti, F., Bauder, A., and Parola, M.: Effect of glaciers on streamflow trends in the Swiss Alps, Water Resour. Res., 46, W10522, doi:10.1029/2009WR009039, 2010.

Peterson, B. J., Holmes, R. M., McClelland, J. W., Vorosmarty, C. J., Lammers, R. B., Shiklomanov, A. I., Shiklomanov, I. A., and Rahmstorf, S.: Increasing river discharge to the Arctic Ocean, Science, 298, 2171-2173, 2002.

Pettersson, R., Jansson, P., and Holmlund, P.: Cold surface layer thinning on Storglaciären, Sweden, observed by repeated ground penetrating radar surveys, J. Geophys. Res., 108, 6004, doi:10.1029/2003JF000024, 2003.

Polyakov, I. V., Bekryaev, R. V., Alekseev, G. V., Bhatt, U. S., Colony, R. L., Johnson, M. A., Maskshtas, A. P., and Walsh, D.: Variability and trends of air temperature and pressure in the maritime Arctic, 1875-2000, J. Climate, 16, 2067-2077, 2003.

Röthlisberger, H. and Lang, H.: Glacial hydrology, edited by: Gurnell, A. M. and Clark, M. J., Glacio-Fluvial Sediment Transfer, Wiley, Chichester, 207-284, 1987.

Rusticucci, M. and Barrucand, M.: Observed trends and changes in temperature extremes over Argentina, J. Clim., 17, 4099-4107, 2004.

Serreze, M. C.,Walsh, J. E., Chapin III, F. S., Osterkamp, T., Dyurgerov, M., Romanovsky, V., Oechel,W. C., Morison, J., Zhang, T., and Barry, R. G.: Observational evidence of recent change in the northern high-latitude environment, Clim. Change, 46, 159-207, 2000.

Stahl, K. and Moore, R. D.: Influence of watershed glacier coverage on summer streamflow in British Columbia, Canada, Water Resour. Res., 42, W06201, doi:10.1029/2006WR005022, 2006.
Stewart, I. T., Cayan, D. R., and Dettinger, M. D.: Changes toward earlier streamflow timing across western North America, J. Climate, 18, 1136-1155, 2005.

Sutton, R. T. and Hodson, D. L. R.: Atlantic Ocean Forcing of North American and European summer climate, Science, 309, 115-118, 2005.

Trenberth, K. E., Jones, P. D., Ambenje, P., Bojariu, R., Easterling, D., Klein Tank, A., Parker, D., Rahimzadeh, F., Renwick, J. A., Rusticucci, M., Soden, B., and Zhai, P.: Observations: Surface and atmospheric climate change, in Climate Change 2007: The Physical Science Basis. Contribution of Working Group I to the Fourth Assessment Report of the Intergovernmental Panel on Climate Change, edited by: edited by: Solomon, S., Qin, D., Manning, M., Chen, Z., Marquis, M., Averyt, K. B., Tignor, M., and Mille, H. L., 235-336, Cambridge Univ. Press, Cambridge, UK, 2007.

Vogel, R. M.: The probability plot correlation coefficient test for the normal, lognormal, and Gumbel distribution hypotheses, Water Resour. Res., 22, 587-590, 1986, correction, 23, 2013, 1987.

Wilson, D., Hisdal, H., and Lawrence, D.: Has streamflow changed in the Nordic countries? - Recent trends and comparisons to hydrological projections, J. Hydrol., 394, 334-346, 2010.

Woo, M. K. and Thorne, R.: Analysis of cold season streamflow response to variability of climate in northwestern North America, Hydrol. Res., 39(4), 257-265, 2008.

Zemp, M., Hoelzle, M., and Haeberli, W.: Six decades of glacier mass-balance observations: a review of the worldwide monitoring network, Ann. Glaciol., 50, 101-111, 2009. 